Article

\title{
An Enhanced Oxidation of Formate on PtNi/Ni Foam Catalyst in an Alkaline Medium
}

\author{
Antanas Nacys * , Dijana Šimkūnaitè, Aldona Balčiūnaitè, Aušrinè Zabielaitè, Daina Upskuvienė, Benjaminas Šebeka, \\ Vitalija Jasulaitienè (D, Vitalij Kovalevskij, Eugenijus Norkus (D) and Loreta Tamašauskaitè-Tamašiūnaitė *(D)
}

check for

updates

Citation: Nacys, A.; Šimkūnaitè, D.;

Balčiūnaitè, A.; Zabielaitè, A.;

Upskuvienè, D.; Šebeka, B.;

Jasulaitienė, V.; Kovalevskij, V.; Norkus,

E.; Tamašauskaitè-Tamašiūnaitè, L.

An Enhanced Oxidation of Formate

on PtNi/Ni Foam Catalyst in an

Alkaline Medium. Crystals 2022, 12,

362. https://doi.org/10.3390/

cryst 12030362

Academic Editor: Stefano Carli

Received: 2 February 2022

Accepted: 7 March 2022

Published: 8 March 2022

Publisher's Note: MDPI stays neutral with regard to jurisdictional claims in published maps and institutional affiliations.

Copyright: (C) 2022 by the authors. Licensee MDPI, Basel, Switzerland. This article is an open access article distributed under the terms and conditions of the Creative Commons Attribution (CC BY) license (https:// creativecommons.org/licenses/by/ $4.0 /)$.
Center for Physical Sciences and Technology, Sauletekio Avenue 3, LT-10257 Vilnius, Lithuania; dijana.simkunaite@ftmc.lt (D.Š.); aldona.balciunaite@ftmc.lt (A.B.); ausrine.zabielaite@ftmc.lt (A.Z.); daina.upskuviene@ftmc.lt (D.U.); benjaminas.sebeka@ftmc.lt (B.Š.); vitalija.jasulaitiene@ftmc.lt (V.J.); vitalij.kovalevskij@ftmc.lt (V.K.); eugenijus.norkus@ftmc.lt (E.N.)

* Correspondence: antanas.nacys@ftmc.lt (A.N.); loreta.tamasauskaite@ftmc.lt (L.T.-T.)

\begin{abstract}
In this study, a platinum-coated $\mathrm{Ni}$ foam catalyst (denoted $\mathrm{PtNi} / \mathrm{Ni}$ foam) was investigated for the oxidation of the formate reaction (FOR) in an alkaline medium. The catalyst was fabricated via a two-step procedure, which involved an electroless deposition of the Ni layer using sodium hypophosphite as a reducing agent and the subsequent electrodeposition of the platinum layer. The $\mathrm{PtNi} / \mathrm{Ni}$ foam catalyst demonstrated enhanced electrocatalytic activity for the FOR in an alkaline medium compared to the $\mathrm{Ni} / \mathrm{Ni}$ foam catalyst and pure Pt electrode. Moreover, the PtNi/Ni foam catalyst promoted the FOR at more negative potentials than the Pt electrode. This contributed to a significant negative shift in the onset potential, indicating the high activity of the catalyst. Notably, in alkaline media with the PtNi/Ni foam catalyst, the FOR proceeds via a direct pathway mechanism without significant accumulation of poisonous carbonaceous species on the $\mathrm{PtNi} / \mathrm{Ni}$ foam catalyst.
\end{abstract}

Keywords: platinum; nickel foam; electroless deposition; formate; oxidation

\section{Introduction}

The large-scale commercialization of formic acid (FA)/formate-based fuel cells is challenging because of the unavailability of highly active, durable, and low-cost catalysts for anodic oxidation reactions. The most promising are based on Pt or Pt-group materials (PGMs) [1-5]. Pd and Pd-based catalysts are the most widely studied and are currently regarded as state-of-the-art electrocatalysts for FA/formate oxidation because of their high catalytic activity and good anti-poisoning properties in acidic and alkaline media [6-8]. Combining Pd with other metals or metal nanoparticles, such as $\mathrm{Ag}$ [8-10], $\mathrm{Cu}$ [10,11], $\mathrm{Ni}$ [9], $\mathrm{CeO}_{2}$ [12], In [13], and B [14], improves the characteristics of the catalysts while simultaneously reducing the cost. In some cases, especially under alkaline conditions, Pd-based catalysts are even more active and less prone to deactivation by carbon monoxide (CO) than Pt-based catalysts [15]; however, their insufficient stability remains a major concern. Meanwhile, significantly less attention has been paid to Pt-based electrodes for the FOR. However, further development is required to mitigate the high cost and low performance of Pt-based catalysts owing to the fast deactivation of the in situ-generated poisonous carbonaceous intermediates, such as $\mathrm{CO}$, and to develop CO-tolerant catalysts. Some efficient ways to overcome the present drawbacks are to decrease the Pt loading and fabricate nanostructured materials with $\mathrm{Pt}$ to exploit its mass activity and stability, or decorate and modify catalysts with Pt heteroatoms for better poison resistance $[8,16,17]$. Another way to enhance Pt electrocatalysis is to control the acidity of fuel solutions by maintaining a low concentration of FA and a high concentration of formate, which results in a smaller volume of FA being adsorbed. This contributes to a lower level of severe Pt poisoning by the adsorbed CO [18]. However, decreasing FA concentration is closely related to decreases in the current density of FA oxidation. Recently, free formate was 
demonstrated to promote anode oxidation in acidic solutions and suppress the poisoning pathway [18]. The FOR demonstrates faster reaction kinetics, a lower overpotential, and less poisoning of the anode catalyst in an alkaline media than in an acidic media [19-22].

Several conventional design principles for catalysts have been applied to improve their poisoning resistance. The following two strategies have been used: (1) Pt is coupled with other metals such as $\mathrm{Ni}$ [23-26], $\mathrm{Au}$ [8,27], Bi [28,29], Sb [30], and $\mathrm{Rh}$ [31], to prevent $\mathrm{CO}$ adsorption on the Pt surface through so-called ensemble and electronic effects, and (2) oxidative removal of adsorbed $\mathrm{CO}$ from the Pt surface is facilitated at low potentials by enriching the surface with oxygen-containing species via a bifunctional mechanism. This may be achieved by alloying $\mathrm{Pt}$ with oxophilic transition metals or metal oxides, such as $\mathrm{NiO}_{x}$ [32-35], $\mathrm{CoO}_{x}$ [32], $\mathrm{Cu}_{2} \mathrm{O}$ [36], $\mathrm{FeO}_{x}$ [37], $\mathrm{MnO}_{x}$ [38,39], and $\mathrm{SnO}_{2}$ [40]. The presence of oxophilic materials, including Ni-oxy species, in the catalyst composition can assist with the electrochemical dissociation of water to form $\mathrm{OH}^{-}$ions at a more negative potential than that required for $\mathrm{OH}^{-}$to be formed in the presence of bare $\mathrm{Pt}[32,41-43]$. This phenomenon aids in the removal of adsorbed surface $\mathrm{CO}\left(\mathrm{CO}_{\mathrm{ads}}\right)$ by oxidation, allowing for the development of $\mathrm{CO}$-tolerant catalysts. In addition, the $\beta-\mathrm{NiOOH}$ phase, which originates from the oxidation of the lower oxidation state $\mathrm{Ni}$ or $\mathrm{NiO}$ through $\mathrm{Ni}(\mathrm{OH})_{2}$, is considered to be the active anti-poison site, and can act as a catalytic mediator through a reversible $\mathrm{Ni}$ (II)/Ni (III) redox system to facilitate a charge transfer for the FA oxidation reaction [32]. Moreover, Ni-based oxides/hydroxides are of significant interest as electrocatalysts because of their low price, nontoxicity, and earth-abundant resources. Recently, the spontaneous deposition of Pt on commercial Ni foams $\left(\mathrm{Ni}_{\text {foam }}\right)$ was used to produce Pt-modified 3D Ni electrodes, which are perfect candidates for efficient catalysis owing to the high surface area and synergistic effects between the Pt nanoparticles and the supporting material [44]. This unique three-dimensional structure benefits significantly from the use of noble metals. As a result, Ni foams with a particular architecture and excellent conductivity have been successively used as supports for the preparation of catalysts for various electrochemical reactions, such as hydrogen evolution [45], water splitting in alkaline media [46], direct ammonia oxidation [47], methanol oxidation [48], ethanol oxidation [49], sodium borohydride hydrolysis [50], borohydride oxidation [51], hydrazine oxidation [52], and urea oxidation [53]. However, there are no reports of $\mathrm{Ni}$ foam as a support for FA oxidation.

Large surfaces are important for the good spacious dispersion of heterogeneous catalysts, as they provide an increased contact area for reactants to facilitate catalysis. Therefore, we deposited a $\mathrm{Ni}$ layer on the $\mathrm{Ni}$ foam surface $\left(\mathrm{Ni} / \mathrm{Ni}_{\text {foam }}\right)$ using the electroless deposition technique. Subsequently, a thin Pt layer was electrochemically deposited on the surface. The electrocatalytic activity of the $\mathrm{PtNi} / \mathrm{Ni}_{\text {foam }}$ catalysts for FOR was evaluated in alkaline media. Owing to the synergy between the active sites of $\mathrm{Pt}$, the porous structure of the Ni-oxy species layer on the Ni foam, and the extremely high specific surface area of the catalyst, the prepared catalyst demonstrated advanced activity in alkaline media and pronounced resistance to poisoning by carbonaceous species.

\section{Materials and Methods}

The Ni foam with 20 pores $/ \mathrm{cm}$, a bulk density of $0.45 \mathrm{~g} \mathrm{~cm}^{-3}$, and a thickness of $1.6 \mathrm{~mm}$ was purchased from GoodFellow GmbH Supplier (Hamburg, Germany). The thin $\mathrm{Ni}$ layer was deposited on $\mathrm{Ni}$ foam, using sodium hypophosphite as a reducing agent described in detail in Ref. [50].

The $\mathrm{Pt}$ thin layer was electroplated on $\mathrm{Ni} / \mathrm{Ni}_{\text {foam }}$ using the electrolyte containing $\mathrm{PtCl}_{2}\left(\mathrm{NH}_{3}\right)_{2}, \mathrm{NH}_{4} \mathrm{NO}_{3}, \mathrm{NH}_{4} \mathrm{OH}$, and $\mathrm{NaNO}_{2}$ (pH 8) at the current density of $1 \mathrm{~A} \mathrm{dm}^{-2}$ for $40 \mathrm{~min}$. The temperature of the electrolyte was kept at a temperature of $95^{\circ} \mathrm{C}$.

The chemical composition of the samples was analyzed using the X-ray photoelectron spectroscopy method employing Kratos AXIS Supra+ spectrometer (Kratos Analytical, Manchester, UK, 2019) with monochromatic Al K $\alpha(1486.6 \mathrm{eV})$ X-ray radiation powered at $225 \mathrm{~W}$. The base pressure in the analysis chamber was less than $1 \times 10^{-8} \mathrm{mbar}$ and a low electron flood gun was used as a charge neutralizer. The survey spectra for each 
sample were recorded at a pass energy of $80 \mathrm{eV}$ with a $1 \mathrm{eV}$ energy step and high-resolution spectra (pass energy $-10 \mathrm{eV}$, in $0.1 \mathrm{eV}$ steps) over individual element peaks. The binding energy scale was calibrated by setting the adventitious carbon peak at $284.8 \mathrm{eV}$. XPS data were converted to VAMAS format and processed using the Avantage Software (Thermo Scientific, East Grinstead, UK).

The morphology and composition of the prepared coatings were investigated by scanning electron microscopy (SEM) using a SEM/FIB workstation Helios NanoLab 650 with an energy dispersive X-ray (EDX) spectrometer INCA Energy 350 X-Max 20. Pt loading was determined by inductively coupled plasma optical emission spectrometry (ICP-OES). It was determined that the Pt loading in the $\mathrm{PtNi} / \mathrm{Ni}_{\text {foam }}$ catalyst was ca. $71 \mu \mathrm{g} \mathrm{cm}{ }^{-2}$.

The oxidation of formate (FOR) was investigated using a Zennium electrochemical workstation (ZAHNER-Elektrik GmbH \& Co.KG, Kronach, Germany). A conventional three-electrode cell was used for electrochemical measurements. The $\mathrm{Ni} / \mathrm{Ni}_{\text {foam }}$ and $\mathrm{PtNi} / \mathrm{Ni}_{\text {foam }}$ catalysts with a geometric area of $2.45 \mathrm{~cm}^{2}$ were employed as working electrodes. $\mathrm{An} \mathrm{Ag} / \mathrm{AgCl} / \mathrm{KCl}(3 \mathrm{M} \mathrm{KCl})$ electrode was used as a reference, Pt sheet with a geometric area of $4 \mathrm{~cm}^{2}$ was used as a counter electrode. For comparison, the Pt bulk electrode with a geometric area of $1 \mathrm{~cm}^{2}$. Cyclic voltammograms $(\mathrm{CVs})$ were recorded at a potential scan rate of $50 \mathrm{mV} \mathrm{s}^{-1}$ from the open-circuit potential value in the anodic voltammetric scan up to $+0.6 \mathrm{~V}$ unless otherwise stated in a $1 \mathrm{M} \mathrm{NaOH}$ solution containing FA concentration in the range of $0.1-0.7 \mathrm{M}$ at a temperature of $25^{\circ} \mathrm{C}$. All reported potential values are referred to as " $\mathrm{Ag} / \mathrm{AgCl}^{\prime}$.

Chronoamperometric measurements were carried out at a constant electrode potential of $-0.6 \mathrm{~V}$ for $2600 \mathrm{~s}$.

\section{Results}

\subsection{Characterization of the Electrodes}

X-ray photoelectron spectroscopy (XPS) was performed to analyze the electronic state of the surface composition of the as-prepared $\mathrm{PtNi} / \mathrm{Ni}_{\text {foam }}$. The $\mathrm{Pt} 4 \mathrm{f}$ spectra reveal a doublet consisting of high-energy ( $\mathrm{Pt} 4 \mathrm{f5} / 2$ ) and low-energy ( $\mathrm{Pt} 4 \mathrm{f7} / 2$ ) bands (Figure 1a). Deconvolution of the latter reveals two peaks centered at 70.9 and $72.4 \mathrm{eV}$, indicating that $\mathrm{Pt}$ is in two different oxidation states, $\mathrm{Pt}(0)$ and $\mathrm{Pt}$ (II), respectively, and the lower binding energy (BE) peak at $70.9 \mathrm{eV}$ is clearly dominant. This indicates that almost all $\mathrm{Pt}$ species grown on $\mathrm{Ni} / \mathrm{Ni}_{\text {foam }}$ exist in a metallic state. The higher $\mathrm{BE}$ peak $(72.4 \mathrm{eV})$ represents $\mathrm{PtO}$ or $\mathrm{Pt}(\mathrm{OH})_{2}$ [54].

The Ni 2 $\mathrm{p}_{3 / 2}$ XPS spectrum splits into three resolved peaks centered at $852.3 \mathrm{eV}, 853.9$, and $855.8 \mathrm{eV}$, indicating the presence of $\mathrm{Ni}, \mathrm{NiO}$, and $\mathrm{Ni}(\mathrm{OH})_{2}$ species, respectively, on the $\mathrm{Ni}_{\text {foam }}$ surface (Figure $1 \mathrm{~b}$ ). The dominant BE peak at $855.8 \mathrm{eV}$ indicates that the $\mathrm{Ni}(\mathrm{OH})_{2}$ species predominates in the catalyst composition. Moreover, the BE peak of $\mathrm{Pt} 4 \mathrm{f}_{7 / 2}$ for the $\mathrm{PtNi} / \mathrm{Ni}_{\text {foam }}$ catalyst shifted from 71.20 to $70.91 \mathrm{eV}$ when compared to that for metallic $\mathrm{Pt}$, suggesting that $\mathrm{Pt}$ undergoes electronic structural changes when it is coupled with $\mathrm{Ni}(\mathrm{OH})_{2}$ [55]. This shift implies that the Ni atoms occupy the Pt lattice and that the metallic grains are intermixed with $\mathrm{Ni}(\mathrm{OH})_{2}[56,57]$. Furthermore, the $\mathrm{O}$ 1s XPS spectrum reveals three resolved peaks centered at 529.8, 531.3, and $532.8 \mathrm{eV}$ (Figure 1c). The lowest energy contributions at 529.8 and $531.3 \mathrm{eV}$ were assigned to oxide/hydroxide species such as $\mathrm{NiO}$ and $\mathrm{Ni}(\mathrm{OH})_{2}$, respectively [45]. The highest $\mathrm{BE}$ value $(532.8 \mathrm{eV})$ generally corresponds to physically adsorbed water molecules $[58,59]$. The coexistence of $\mathrm{Pt}$ and $\mathrm{Ni}(\mathrm{OH})_{2}$ species was determined by XPS analysis and is supported by cyclic voltammetry measurements.

The cyclic voltammograms (CVs) of the bare $\mathrm{Pt}$ and $\mathrm{PtNi} / \mathrm{Ni}_{\text {foam }}$ electrodes in $1 \mathrm{M}$ $\mathrm{NaOH}$ solution measured at a potential scan rate of $50 \mathrm{mV} \mathrm{s}^{-1}$ are displayed in Figure 2 . The existence of a pair of coupled peaks at ca. $+0.46 \mathrm{~V}$ is generally attributed to the reversible transformation of $\mathrm{Ni}$ (II)/ $\mathrm{Ni}$ (III) species via the redox reaction between $\mathrm{Ni}(\mathrm{OH})_{2}$ and $\mathrm{NiOOH}$, according to the following Equation (1) [60]:

$$
\mathrm{Ni}(\mathrm{OH})_{2}+\mathrm{OH}^{-} \leftrightarrow \mathrm{NiOOH}+\mathrm{H}_{2} \mathrm{O}+\mathrm{e}^{-}
$$






(a)

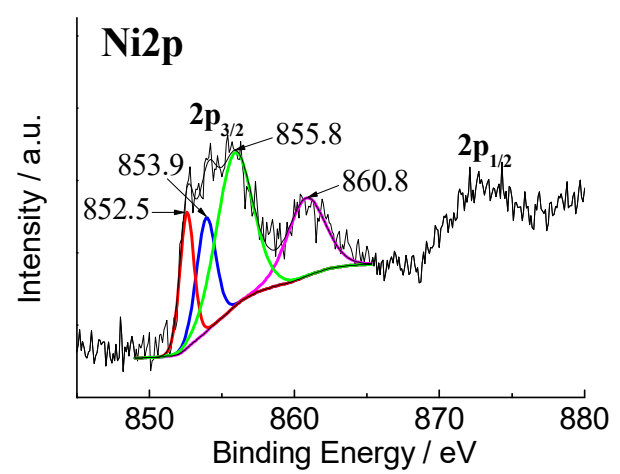

(b)

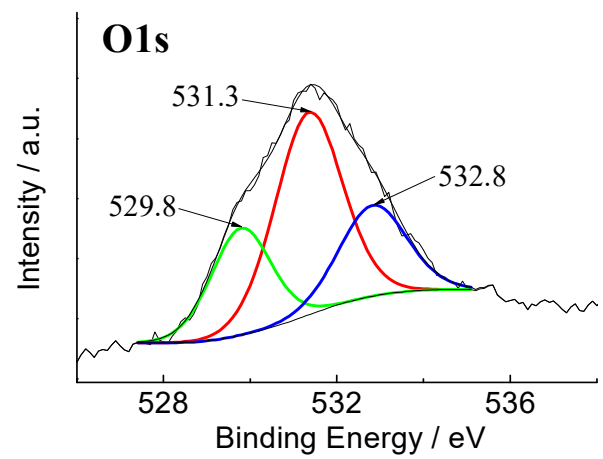

(c)

Figure 1. High-resolution XPS spectra of PtNi/Ni $\mathrm{foam}_{\text {f }}$ (a) Pt 4f; (b) Ni 2p; (c) O1s.

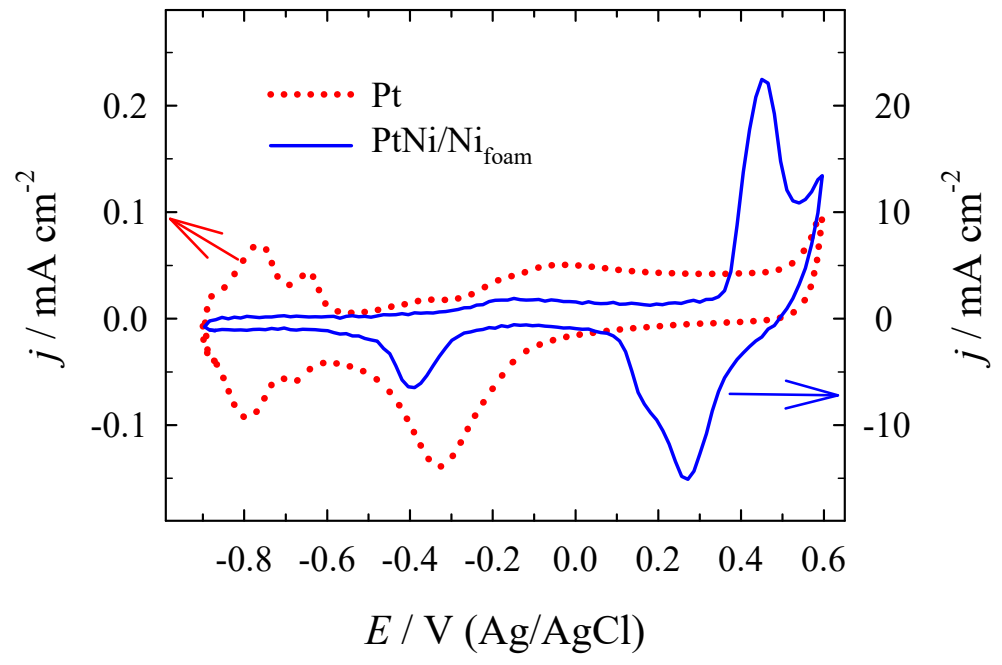

Figure 2. $\mathrm{CVs}$ of $\mathrm{Pt}$ (red dotted line) and $\mathrm{PtNi} / \mathrm{Ni}_{\text {foam }}$ (solid blue line) were recorded in $1 \mathrm{M} \mathrm{NaOH}$ solution at a scan rate of $50 \mathrm{mV} \mathrm{s}^{-1}$.

The presence of $\mathrm{Pt}$ on the surface of the $\mathrm{Ni} / \mathrm{Ni}_{\text {foam }}$ electrode was confirmed by the cathodic peak located at ca. $-0.4 \mathrm{~V}$ in the alkaline $1 \mathrm{M} \mathrm{NaOH}$ solution. The electrochemically active surface areas (ECSAs) of the prepared $\mathrm{Pt}$ and $\mathrm{PtNi} / \mathrm{Ni}_{\text {foam }}$ catalysts were determined from the CVs recorded in a deaerated $0.5 \mathrm{M} \mathrm{H}_{2} \mathrm{SO}_{4}$ solution at a scan rate of $50 \mathrm{mV} \mathrm{s}^{-1}$ (Figure S1, Supplementary Material) by calculating the charge associated with hydrogen adsorption at $210 \mu \mathrm{C} \mathrm{cm}{ }^{-2}$ [61]. The ECSA for the PtNi/ $\mathrm{Ni}_{\text {foam }}$ electrode is $71 \mathrm{~cm}^{2}$, and that for the bare $\mathrm{Pt}$ substrate is $1.5 \mathrm{~cm}^{2}$. The above results reveal that the $\mathrm{PtNi} / \mathrm{Ni}_{\text {foam }}$ electrode has significantly higher current values and a larger surface area than the bare $\mathrm{Pt}$ substrate, and it outperforms the Pt electrode ca. 47-fold. 
The electrochemical performance of the $\mathrm{Pt}$ and $\mathrm{PtNi} / \mathrm{Ni}_{\text {foam }}$ catalysts was evaluated by progressively increasing the anodic reverse potential limit $\left(E_{\mathrm{ra}}\right)$. A series of $\mathrm{CVs}$ for $\mathrm{Pt}$ and $\mathrm{PtNi} / \mathrm{Ni}_{\text {foam }}$ catalysts were recorded in a $1 \mathrm{M} \mathrm{NaOH}$ solution at different $E_{\text {ra }}$ values at a scan rate of $50 \mathrm{mV} \mathrm{s}^{-1}$ (Figure 3). The CV curves of the bare Pt electrodes (Figure 3a) are consistent with those typically found for bare Pt electrodes in an alkaline solution. They are characterized by the following three potential regions: (a) a hydrogen adsorption/desorption region $(-0.9<E<-0.6 \mathrm{~V})$, (b) a double layer region $(-0.6<E<-0.45 \mathrm{~V})$, and (c) a hydroxide-oxide formation region $(-0.45<E<+0.6 \mathrm{~V})$ [62-64]. The applied potential region can generate two types of oxygen-containing species, namely, $\mathrm{PtOH}$ and $\mathrm{PtO}$ [65]. This common potential domain, up to ca. $-0.10 \mathrm{~V}$, is attributed to $\mathrm{OH}^{-}$ion electroabsorption with charge transfer and the formation of surface hydroxides $\left(\mathrm{OH}^{-} \rightarrow \mathrm{OH}_{\mathrm{ad}}+\mathrm{e}^{-}\right.$in alkaline solutions) $[63,66,67]$. This potential domain is associated with reversible and weak $\mathrm{OH}_{\mathrm{ad}}$ adsorption before the oxide layer formation. A more positive $E$ domain represents the only somewhat reversible formation of strongly bound $\mathrm{OH}_{\text {ad }}$ species and high-valent oxides. The most positive potential region up to $+0.6 \mathrm{~V}$ is attributed to stoichiometrically different $\mathrm{Pt}-\mathrm{OH}$ species that transform into $\mathrm{Pt}_{-} \mathrm{O}^{-}, \mathrm{Pt}=\mathrm{O}$, or $\mathrm{Pt}_{2}=\mathrm{O}$, depending on the surface coverage of strongly adsorbed $\mathrm{OH}_{\mathrm{ad}}$.

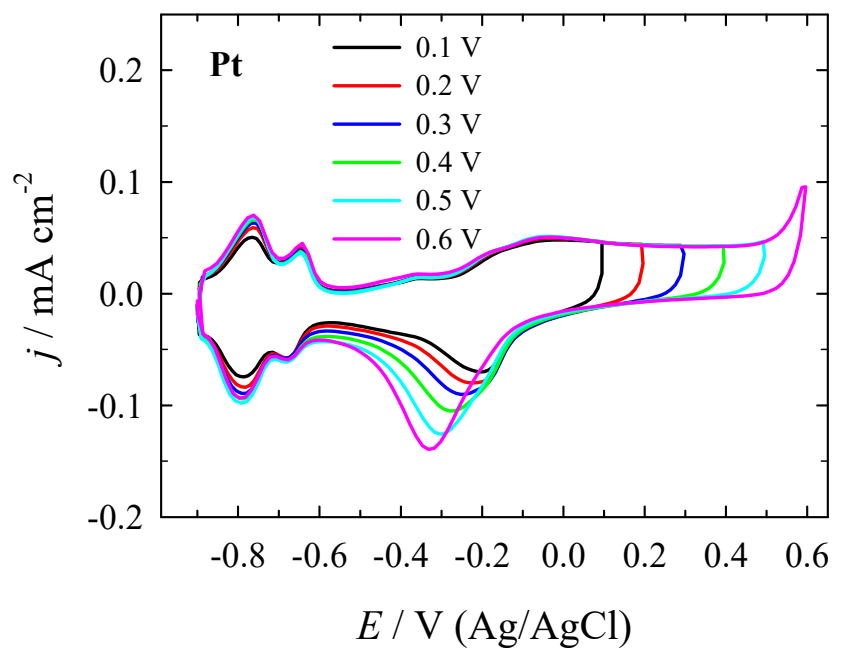

(a)

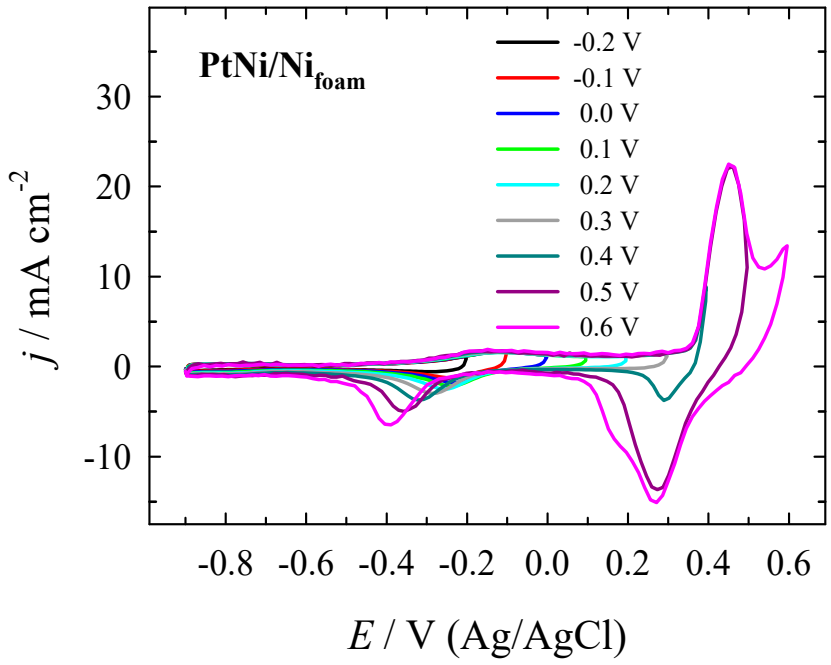

(b)

Figure 3. The $\mathrm{CVs}$ of $\mathrm{Pt}(\mathbf{a})$ and $\mathrm{PtNi} / \mathrm{Ni}_{\text {foam }}(\mathbf{b})$ catalysts at the different anodic potential limit $\left(E_{\mathrm{ra}}\right)$ were recorded in $1 \mathrm{M} \mathrm{NaOH}$ solution at a scan rate of $50 \mathrm{mV} \mathrm{s}^{-1}$.

The cathodic peak generated in the backward (cathodic voltammetric) scan when the electrode potential was scanned at progressively more positive values was attributed to the reduction of Pt oxides, which increased and shifted to more negative potential values, indicating the formation of irreversible oxide species.

Meanwhile, the hydrogen adsorption/desorption peaks at the bare Pt electrode changed significantly less in response to the applied $E_{\text {ra }}$ than those of Pt oxides. However, the processes mentioned above in an alkaline medium are not well separated in potential ranges, as in the case of an acidic medium [68,69]. The coupled $\mathrm{H}$ and $\mathrm{OH}$ adsorption/desorption processes in alkaline media are thought to occur reversibly up to ca. $+0.65 \mathrm{~V}$ vs. RHE for $\mathrm{Pt}(100)$ and $\mathrm{Pt}$ (110), respectively. The $\mathrm{OH}^{-}$adsorption on $\mathrm{Pt}$ in an alkaline medium begins quite low at (ca. $+0.35 \mathrm{~V}$ vs. RHE) $[68,69]$, as soon as the desorption of hydrogen ceases. Notably, the presence of small quantities of adsorbed $\mathrm{OH}_{\mathrm{ad}}$ species on the Pt surface was confirmed, even in the $\mathrm{H}_{\text {upd }}$ region in alkaline solutions $[64,66]$. Thus, the coupled competing adsorption/desorption processes of $\mathrm{H}_{\mathrm{upd}}$ and $\mathrm{OH}_{\mathrm{ad}}$ proceeded in the $\mathrm{H}_{\text {upd }}$ region.

Similarly, CVs were recorded for the $\mathrm{PtNi} / \mathrm{Ni}_{\text {foam }}$ electrode with a gradual increase in the upper $E_{\text {ra }}$ (up to $+0.6 \mathrm{~V}$, Figure $3 \mathrm{~b}$ ). In contrast to the CVs determined for the $\mathrm{Pt}$ 
electrode, those for $\mathrm{PtNi} / \mathrm{Ni}_{\text {foam }}$ reveal a pronounced redox current peak pair at ca. $+0.46 \mathrm{~V}$, which was attributed to the reversible transformation of $\mathrm{Ni}$ (II)/ $\mathrm{Ni}$ (III) species during the anodic and cathodic scans. With an increase in the upper $E_{\mathrm{ra}}$, a slight negative shift of the Pt oxide formation/reduction potentials was observed, together with an increase in the corresponding current peak values during both anodic and cathodic scans. Meanwhile, almost complete suppression of the peak current was observed in the hydrogen adsorption/desorption domain, unlike in bulk Pt. The corresponding Pt oxide reduction current density peak values $\left(j_{\mathrm{pc}}\right)$ for the $\mathrm{Pt}$ and $\mathrm{PtNi} / \mathrm{Ni}_{\text {foam }}$ catalysts determined in a $1 \mathrm{M} \mathrm{NaOH}$ solution with increasing $E_{\mathrm{ra}}$ are presented in Table 1 . The results clearly reveal that $j_{\mathrm{pc}}$ shifted to more negative potential regions. The reduction current density peak values for the $\mathrm{PtNi} / \mathrm{Ni}_{\text {foam }}$ catalysts increased by ca. 39.78 and 46.49 times compared to those for the bare Pt electrode, with increases in $E_{\text {ra }}$ of +0.5 or $+0.6 \mathrm{~V}$, respectively. These data indicate that when the oxidation of $\mathrm{Ni}^{2+}$ to $\mathrm{Ni}^{3+}$ is achieved, the reduction of more $\mathrm{Pt}$ oxides to metallic $\mathrm{Pt}$ are revealed on the backward scan, demonstrating the synergy between the $\mathrm{Pt}$ and Ni species.

Table 1. Comparison of electrochemical activities for the bare Pt and PtNi/Ni $i_{\text {foam }}$ catalysts in a $1 \mathrm{M}$ $\mathrm{NaOH}$ solution with respect to different anodic potential limits $\left(E_{\mathrm{ra}}\right)$.

\begin{tabular}{|c|c|c|c|c|c|}
\hline \multirow{2}{*}{$E_{\mathrm{ra}}, \mathrm{V}$} & $E_{\mathrm{pc}}, \mathrm{V}$ & $j_{\mathrm{pc}}, \mathrm{mA} \mathrm{cm}{ }^{-2}$ & $E_{\mathrm{pc}}, \mathrm{V}$ & $j_{\mathrm{pc}}, \mathrm{mA} \mathrm{cm} \mathrm{cm}^{-2}$ & \multirow{2}{*}{$\begin{array}{c}j_{\mathrm{pc}} \mathbf{P t N i} / \mathbf{N i}_{\text {foam }} / \\
j_{\mathrm{pc}} \mathbf{P t}\end{array}$} \\
\hline & \multicolumn{2}{|c|}{$\mathbf{P t}$} & \multicolumn{2}{|c|}{$\mathrm{PtNi} / \mathrm{Ni}_{\text {foam }}$} & \\
\hline+0.1 & -0.205 & -0.069 & -0.235 & -2.151 & 30.77 \\
\hline+0.2 & -0.221 & -0.079 & -0.256 & -2.508 & 31.39 \\
\hline+0.3 & -0.252 & -0.090 & -0.288 & -2.988 & 33.13 \\
\hline+0.4 & -0.281 & -0.105 & -0.321 & -3.711 & 35.32 \\
\hline+0.5 & -0.303 & -0.125 & -0.356 & -5.004 & 39.78 \\
\hline+0.6 & -0.332 & -0.139 & -0.389 & -6.489 & 46.49 \\
\hline
\end{tabular}

\subsection{Electrocatalytic Evaluation for Formate Oxidation}

The electrocatalytic activity of the $\mathrm{Pt}$ and $\mathrm{PtNi} / \mathrm{Ni}_{\text {foam }}$ catalysts in a $1 \mathrm{M} \mathrm{NaOH}$ solution containing $0.3 \mathrm{M}$ or $0.5 \mathrm{M}$ FA with different $E_{\mathrm{ra}}$ was evaluated by the $\mathrm{CV}$ measurements at a potential scan rate of $50 \mathrm{mV} \mathrm{s}^{-1}$ (Figure 4). Stabilized CVs of FOR for the Pt catalyst plotted in Figure $4 \mathrm{a}$, b reveal one broad peak on the anodic scan, followed by another on the backward scan, regardless of the $E_{\mathrm{ra}}$ applied. Meanwhile, the first scans presented in Figure S2 (Supplementary Material) for different FA concentrations are significantly different from the stabilized ones. Three current peaks (labeled Peak I, Peak II, and Peak III) can be observed in the positive-going potential scan (solid lines), and one more peak (labeled Peak IV, dashed lines) appears in the negative-going potential scan. The nature of those peaks can be interpreted regarding the fact that all FA solutions with different concentrations studied in our work are strongly alkaline, and that the pKa of $\mathrm{HCOOH}$ is well above $~ 3.8$; therefore, it is inevitable that a formate $\left(\mathrm{HCOO}^{-}\right)$oxidation reaction will occur [19]. A dual-pathway mechanism, analogous to FAO in acidic media, takes place for formate oxidation in alkaline media on polycrystalline $\mathrm{Pt}$ at $\mathrm{pH} \approx 14$ [19]. Formate typically undergoes oxidation through a reactive intermediate either directly to $\mathrm{CO}_{2}$, or indirectly through a strongly chemisorbed intermediate $\left(\mathrm{CO}_{\mathrm{ad}}\right)$ that is further oxidized to $\mathrm{CO}_{2}$ at higher potentials. Additionally, a third independent pathway, involving formate oxidation via the formation of less-active surface formate $\left(\mathrm{HCOO}_{\mathrm{ads}}\right)$, and its oxidation to $\mathrm{CO}_{2}$ on the Pt surface at significantly higher potentials, should be considered [70]. 




(a)

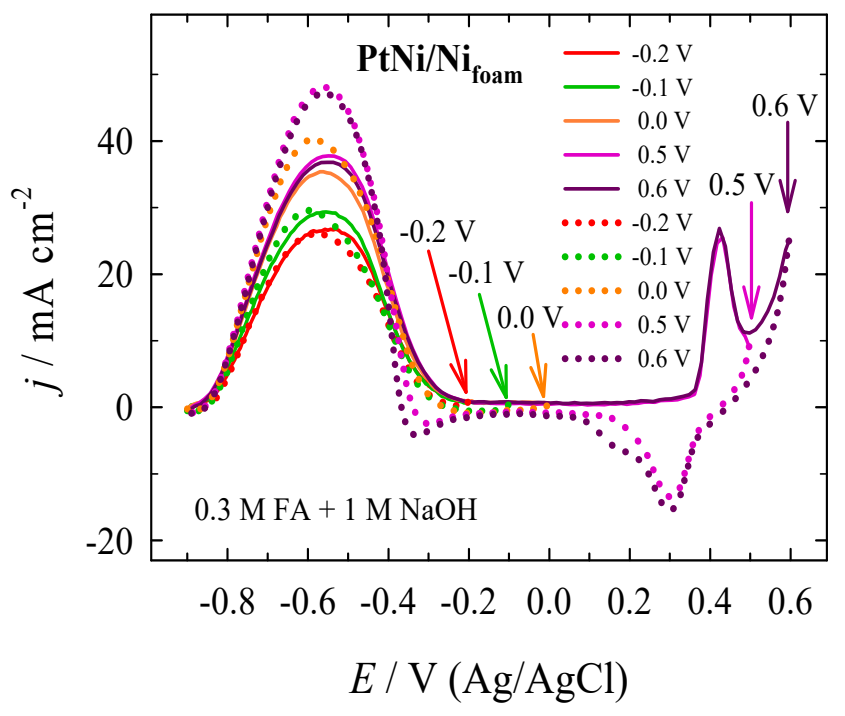

(c)

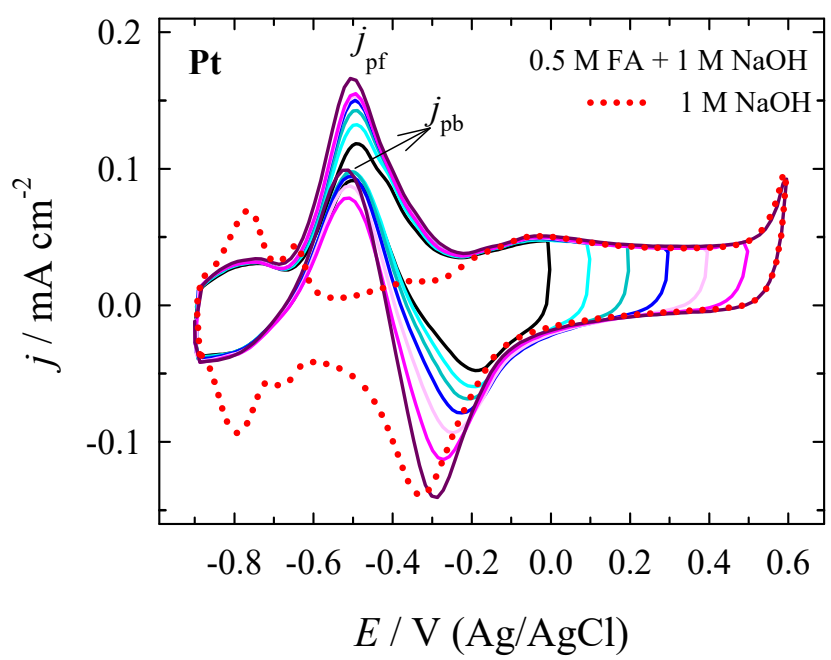

(b)

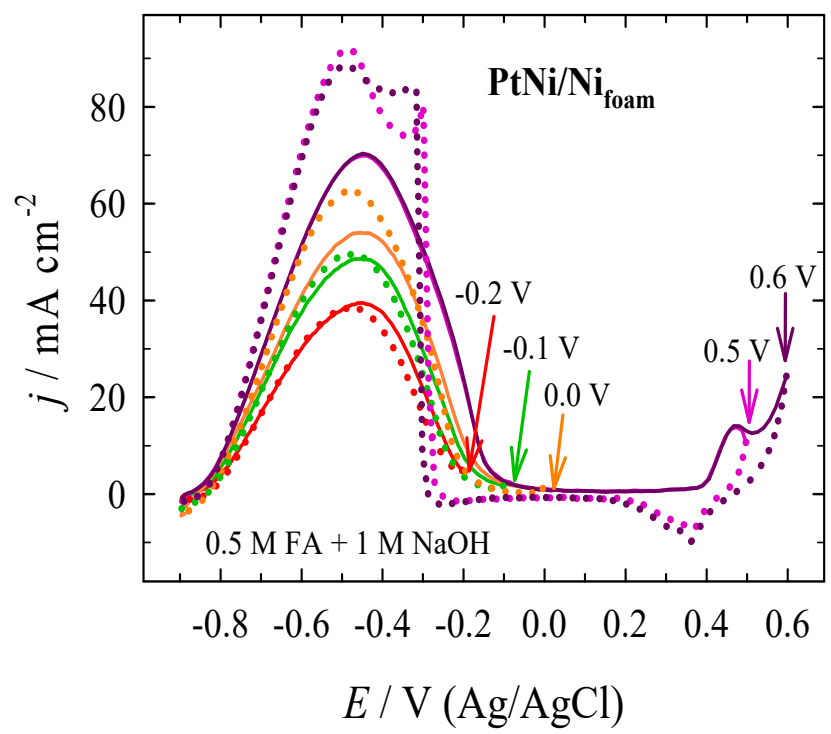

(d)

Figure 4. Stabilized CVs of the $\mathrm{Pt}(\mathbf{a}, \mathbf{b})$ and $\mathrm{PtNi} / \mathrm{Ni}_{\text {foam }}(\mathbf{c}, \mathbf{d})$ catalysts at different $E_{\text {ra }}$ recorded in a $1 \mathrm{M} \mathrm{NaOH}$ solution containing different FA concentrations of $0.3 \mathrm{M}(\mathbf{a}, \mathbf{c})$ or $0.5 \mathrm{M}(\mathbf{b}, \mathbf{d})$ at a scan rate of $50 \mathrm{mV} \mathrm{s}^{-1}$. (a,b) The dotted lines indicate the stabilized CV curve of Pt recorded in a $1 \mathrm{M}$ $\mathrm{NaOH}$ solution at a scan rate of $50 \mathrm{mV} \mathrm{s}^{-1}$. (c,d) Solid lines and dotted lines represent the anodic and cathodic potential scans, respectively, in the CVs.

The first peak (I) at ca. $-0.5 \mathrm{~V}$ in Figure S2 was assigned to the direct oxidation of formate, and a second hardly discernible peak (II) at ca. $-0.35 \mathrm{~V}$ was attributed to the indirect oxidation pathway via the strongly chemisorbed intermediate $\mathrm{CO}_{\mathrm{ads}}$ [19]. The third peak (III) at ca. $+0.00 \mathrm{~V}$ indicates an independent pathway of formate oxidation via the formation of the less active surface formate $\left(\mathrm{HCOO}_{\mathrm{ads}}\right)$ and its oxidation to $\mathrm{CO}_{2}$ [70]. At ca. $-0.5 \mathrm{~V}$, the last peak (IV) on the reverse potential scan developed in the electrode potential region where no surface hydrogen adsorption occurs. The oxide was reduced almost to completion. The properties of peak IV depend on several factors, such as the reduction of surface oxides, $\mathrm{CO}$ adsorption on the electrode surface, and mass transfer limitation [70]. As the catalyst active sites were cleaned of adsorbed intermediates at high potentials and the Pt oxides/hydroxides were reduced, this peak is most likely related to the direct oxidation pathway (dehydrogenation). Moreover, the presence of this peak and the potential region of peak I both suggest a similar reaction pathway. Peak IV might have 
been influenced by the oxidation of adsorbed residual species in this potential region, but this does not seem likely under the conditions of our experiment.

An increase in the number of applied scan cycles leads to a change in the slight shape transformation of the stabilized CVs, resulting in a broader formate oxidation current density peak on the bare Pt electrode (Figure $4 a, b)$. Current density peaks for FO on forward (anodic voltammetric) and backward scans are denoted $\left(j_{\mathrm{pf}}\right)$ and $\left(j_{\mathrm{pb}}\right)$, respectively. It is impossible to propose an unambiguous treatment of the origin of the oxidation peak obtained in the case of stabilized CVs on the bare Pt electrode, as the overlapping of the peaks is not excluded, and the merging of direct and indirect FO pathways is presumable.

The stabilized CVs (Figure 4a,b) clearly reveal that a progressive increase in the upper anodic potential limit accelerates the formation of Pt oxides and results in higher Pt oxide reduction peak values on the negative-going potential scans and higher FO current density peak values on the forward-going potential scans of the Pt electrode. These results are similar to those obtained when the FA concentration is increased from 0.3 to $0.5 \mathrm{M}$.

The increase in the current density peak value for the Pt oxide reduction to metallic Pt occurs with a reduction potential shift to a more negative value. This indicates a more difficult reduction of Pt oxides. Meanwhile, the FO potential for both $j_{\mathrm{pf}}$ and $j_{\mathrm{pb}}$ remains almost unchanged regardless of the applied $E_{\mathrm{ra}}$ value. The $j_{\mathrm{pf}}$ value triples if $E_{\mathrm{ra}}$ is changed from -0.2 to $+0.6 \mathrm{~V}$ for $\mathrm{FO}$ at the Pt electrode in $0.3 \mathrm{M} \mathrm{FA}+1 \mathrm{M} \mathrm{NaOH}$ solution (Figure 4a) and is ca. 1.40 times higher in $0.5 \mathrm{M} \mathrm{FA}+1 \mathrm{M} \mathrm{NaOH}$ solution (Table 2).

Table 2. Summary of electrochemical measurements at Pt catalyst in $1 \mathrm{M} \mathrm{NaOH}+0.5 \mathrm{M}$ FA from the data in Figure $4 b$.

\begin{tabular}{ccccccc}
\hline$E_{\mathbf{r a}}, \mathbf{V}$ & $E_{\mathbf{p f}}, \mathbf{V}$ & $j_{\mathbf{p f}}, \mathbf{m A ~ c m} \mathbf{~ c m}^{-2}$ & $E_{\mathbf{p b}}, \mathbf{V}$ & $j_{\mathbf{p b}}, \mathbf{m A ~ c m} \mathbf{~ c}^{-2}$ & $j_{\mathbf{p f}} / j_{\mathbf{p b}}$ & $j_{\mathbf{p f}} \mathbf{a t} \mathbf{X ~ V} / j_{\mathbf{p f}} \mathbf{a t}+\mathbf{0 . 0} \mathbf{~ V}$ \\
\hline+0.0 & -0.493 & 0.1185 & -0.497 & 0.0913 & 1.30 & 1.00 \\
\hline+0.1 & -0.490 & 0.1322 & -0.500 & 0.0976 & 1.35 & 1.12 \\
\hline+0.2 & -0.500 & 0.1423 & -0.507 & 0.0978 & 1.46 & 1.20 \\
\hline+0.3 & -0.495 & 0.1501 & -0.501 & 0.0943 & 1.59 & 1.27 \\
\hline+0.4 & -0.499 & 0.1537 & -0.507 & 0.0875 & 1.76 & 1.30 \\
\hline+0.5 & -0.493 & 0.1549 & -0.509 & 0.0785 & 1.97 & 1.31 \\
\hline+0.6 & -0.507 & 0.1661 & -0.512 & 0.0989 & 1.68 & 1.40 \\
\hline
\end{tabular}

The presence of an extremely clean metallic Pt surface thermodynamically improves the oxidation reaction of $\mathrm{CO}_{\mathrm{ads}}$. However, the decrease in $j_{\mathrm{pb}}$ with increasing $E_{\mathrm{ra}}$ in the forward scan in $0.3 \mathrm{M} \mathrm{FA}+1 \mathrm{M} \mathrm{NaOH}$ solution is associated with the oxidation of residual incompletely oxidized carbon species on the catalyst surface rather than the oxidation of freshly chemisorbed species. Meanwhile, the absence of a clear correlation between the change in $j_{\mathrm{pb}}$ value and the $E_{\mathrm{ra}}$ in $0.5 \mathrm{M} \mathrm{FA}+1 \mathrm{M} \mathrm{NaOH}$ solution could be explained by the competitive oxidation between residual incompletely oxidized carbon species and freshly chemisorbed species due to the activation of the surface by the reduction of Pt oxides and/or hydroxides. The presence of $\mathrm{Pt}$ oxides and/or hydroxide oxides (such as $\mathrm{PtO}_{2}$ ) on the catalyst surface is thought to help oxidize the $\mathrm{CO}_{\mathrm{ad}}$, and thus, reduce catalyst poisoning, similar to the case of $\mathrm{PdO}_{2}$ and $\mathrm{Au}_{2} \mathrm{O}_{3}$ in an alkaline media [6,70-72]. Nevertheless, the scope of the results indicates that the increase in the upper $E_{\text {ra }}$ appears to favor the direct oxidation pathway in all cases for peaks I and IV.

Similarly, stabilized CVs were recorded for the $\mathrm{PtNi} / \mathrm{Ni}_{\text {foam }}$ catalyst with increasing $E_{\mathrm{ra}}$ (Figure $4 \mathrm{c}, \mathrm{d}$ ). One broad current density peak was generated in the negative potential region of the $\mathrm{PtNi} / \mathrm{Ni}_{\text {foam }}$ catalyst, characterized by $\mathrm{FO}$ via a direct pathway that was followed by a clear current density peak at positive potentials corresponding to the $\mathrm{Ni}(\mathrm{OH}) / \mathrm{NiOOH}$ surface transformation. The formate oxidation current density peak values increased tremendously with increases in the positively going potential limit. Current density peak 
values ca. 400 times higher than those obtained with the bare Pt electrode were observed, confirming that the ECSAs of $\mathrm{PtNi} / \mathrm{Ni}_{\text {foam }}$ are much larger and that there are many more active sites that facilitate significantly improved FO catalytic reactions owing to the synergy between the Pt and the porous Ni-coated foam substrate. The increase in FA concentration contributes similarly to current growth. A summary of the electrochemical measurements of the $\mathrm{PtNi} / \mathrm{Ni}_{\text {foam }}$ catalyst in $1 \mathrm{M} \mathrm{NaOH}$ with 0.3 or $0.5 \mathrm{M} \mathrm{FA}$ (Figure $4 \mathrm{c}, \mathrm{d}$ ) is presented in Tables 3 and 4 . The $j_{\mathrm{pf}}$ value increased ca. 1.4 or 1.8 times for the $\mathrm{PtNi} / \mathrm{Ni}_{\text {foam }}$ catalyst in $1 \mathrm{M} \mathrm{NaOH}$ containing $0.3 \mathrm{M}$ or $0.5 \mathrm{M} \mathrm{FA}$, respectively, when the $E_{\mathrm{ra}}$ was changed from -0.2 to $+0.6 \mathrm{~V}$. The $j_{\mathrm{pf}} / j_{\mathrm{pb}}$ ratio varied from ca. $1.0-0.8$, confirming that the incorporation of Ni oxy-species effectively improves the electrocatalytic kinetics of the Pt-based catalysts and can prevent the accumulation of incompletely oxidized carbonaceous species $\left(\mathrm{CO}_{\mathrm{ads}}\right)$, directing the FOR toward the dehydrogenation pathway.

Table 3. Summary of electrochemical measurements at $\mathrm{PtNi} / \mathrm{Ni}_{\text {foam }}$ catalyst in $1 \mathrm{M} \mathrm{NaOH}+0.3 \mathrm{M}$ FA from the data in Figure 4c.

\begin{tabular}{|c|c|c|c|c|c|c|}
\hline$E_{\mathrm{ra}}, \mathrm{V}$ & $E_{\mathrm{pf}}, \mathrm{V}$ & $j_{\mathrm{pf}}, \mathrm{mA} \mathrm{cm}^{-2}$ & $E_{\mathrm{pb}}, \mathrm{V}$ & $j_{\mathrm{pb}}, \mathrm{mA} \mathrm{cm}^{-2}$ & $j_{\mathrm{pf}} / j_{\mathrm{pb}}$ & $j_{\mathrm{pf}}$ at $X V / j_{\mathrm{pf}}$ at $-0.2 \mathrm{~V}$ \\
\hline-0.2 & -0.530 & 26.75 & -0.591 & 25.99 & 1.03 & 1.00 \\
\hline-0.1 & -0.563 & 29.30 & -0.597 & 29.57 & 0.99 & 1.10 \\
\hline+0.0 & -0.570 & 35.38 & -0.582 & 40.10 & 0.88 & 1.32 \\
\hline+0.5 & -0.549 & 37.77 & -0.565 & 48.04 & 0.79 & 1.41 \\
\hline+0.6 & -0.552 & 36.80 & -0.557 & 47.22 & 0.78 & 1.38 \\
\hline
\end{tabular}

Table 4. Summary of electrochemical measurements at $\mathrm{PtNi} / \mathrm{Ni}_{\text {foam }}$ catalyst in $1 \mathrm{M} \mathrm{NaOH}+0.5 \mathrm{M}$ FA for the data in Figure 4d.

\begin{tabular}{ccccccc}
\hline$E_{\mathbf{r a}}, \mathbf{V}$ & $E_{\mathbf{p f}}, \mathbf{V}$ & $j_{\mathbf{p f}}, \mathbf{m A ~ c m} \mathbf{~ c m}^{-2}$ & $E_{\mathbf{p b}}, \mathbf{V}$ & $j_{\mathbf{p b}}, \mathbf{m A ~ c m} \mathbf{~ c m}^{-2}$ & $j_{\mathbf{p f}} / j_{\mathbf{p b}}$ & $j_{\mathbf{p f}}$ at X V/j $j_{\mathbf{p f}}$ at $-\mathbf{0 . 2} \mathbf{V}$ \\
\hline-0.2 & -0.461 & 39.48 & -0.478 & 38.40 & 1.03 & 1.00 \\
\hline-0.1 & -0.446 & 48.73 & -0.490 & 49.55 & 0.98 & 1.23 \\
\hline+0.0 & -0.454 & 54.00 & -0.483 & 62.53 & 0.86 & 1.37 \\
\hline+0.5 & -0.451 & 69.91 & -0.481 & 91.95 & 0.76 & 1.77 \\
\hline+0.6 & -0.449 & 70.32 & -0.496 & 88.61 & 0.79 & 1.78 \\
\hline
\end{tabular}

The influence of the first applied potential scan cycles recorded for the $\mathrm{PtNi} / \mathrm{Ni}_{\text {foam }}$ catalyst for different $E_{\mathrm{ra}}$ values in alkaline FA was investigated. For the sake of simplicity, only the positive-going potential CVs with two different $E_{\text {ras }}(-0.2$ and $+0.6 \mathrm{~V})$ for the $\mathrm{PtNi} / \mathrm{Ni}_{\text {foam }}$ catalyst in a $1 \mathrm{M} \mathrm{NaOH}$ solution, containing different FA concentrations of 0.1 , 0.3 , and $0.5 \mathrm{M}$, are presented in Figure 5. Successive cycling in the potential region with an $E_{\text {ra }}$ of $-0.2 \mathrm{~V}$ resulted in an apparent $j_{\mathrm{pf}}$ decrease at all FA concentrations applied to the $\mathrm{PtNi} / \mathrm{Ni}_{\text {foam }}$ catalyst. Meanwhile, when the $E_{\mathrm{ra}}$ was decreased to $-0.6 \mathrm{~V}$ to include the potential window for the oxidation of $\mathrm{Ni}^{2+}$ to $\mathrm{Ni}^{3+}$, the $j_{\mathrm{pf}}$ increased (unlike when $\left.E_{\mathrm{ra}}=-0.2 \mathrm{~V}\right)$ and increased further with increasing FA concentration, indicating an improvement in FO. Changing the $E_{\mathrm{ra}}$ from -0.2 to $+0.6 \mathrm{~V}$ resulted in increases of ca. 1.3, 1.4, and even 1.8 times for the $I_{\mathrm{pf}}$ values, for $0.1,0.3$, and $0.5 \mathrm{M}$ FA containing alkaline solutions, respectively, on the $\mathrm{PtNi} / \mathrm{Ni}_{\text {foam }}$ catalyst. An increase in FA concentration from 0.1 to $0.5 \mathrm{M}$ led to ca. 4.4-6.1-fold increased $j_{\mathrm{pf}}$ values when the upper potential limit was $-0.2 \mathrm{~V}$ or $+0.6 \mathrm{~V}$. Furthermore, a decrease in $j_{\mathrm{pb}}$ values can be observed on the negative-going potential scans presented in Figure S3 (Supplementary Material), regardless of the $E_{\mathrm{ra}}$ value applied. Notably, when $E_{\mathrm{ra}}=-0.6 \mathrm{~V}$, the forward and backward-going current density peak values become closer to each other, indicating better catalyst tolerance to the accumulation of carbonaceous species. 


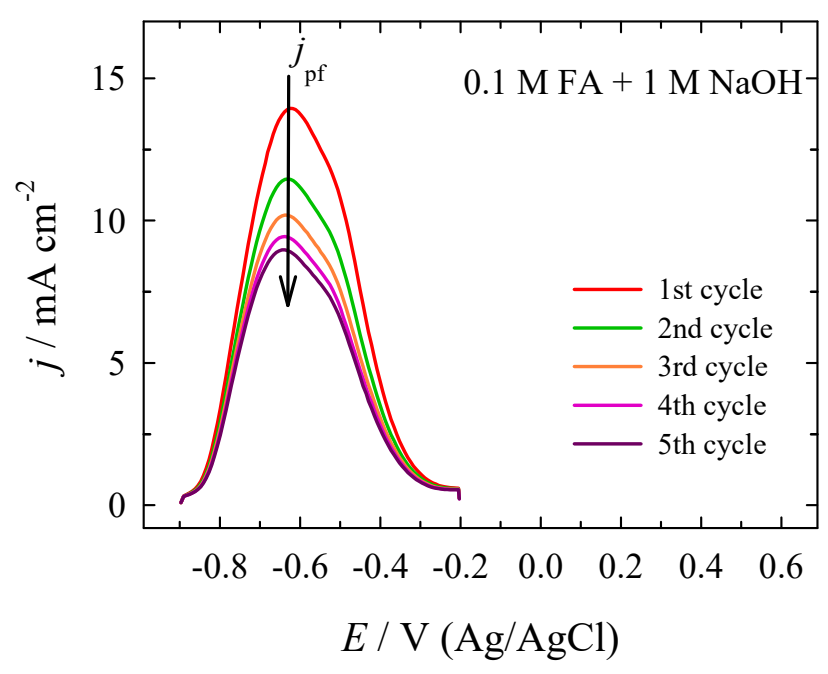

(a)

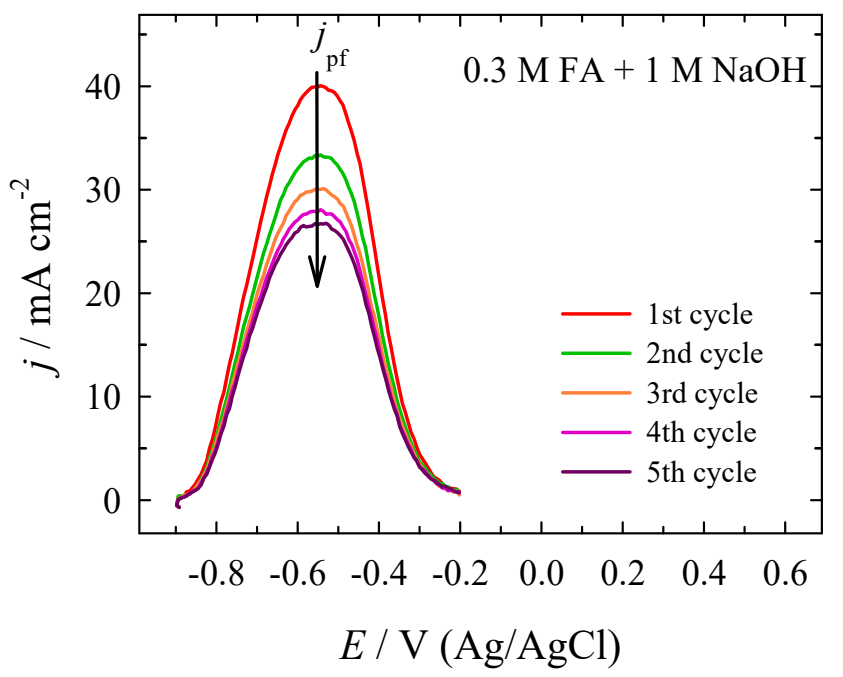

(c)

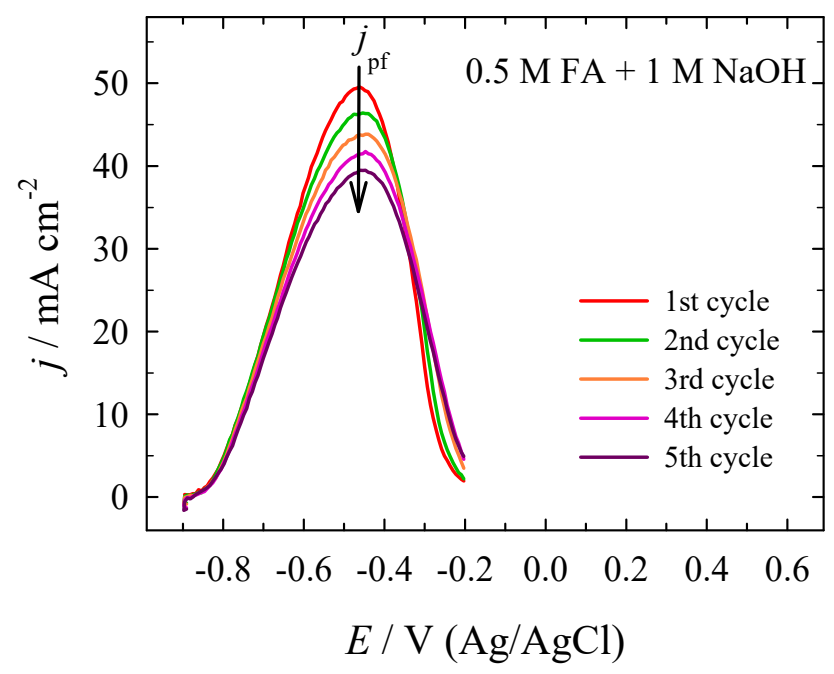

(e)

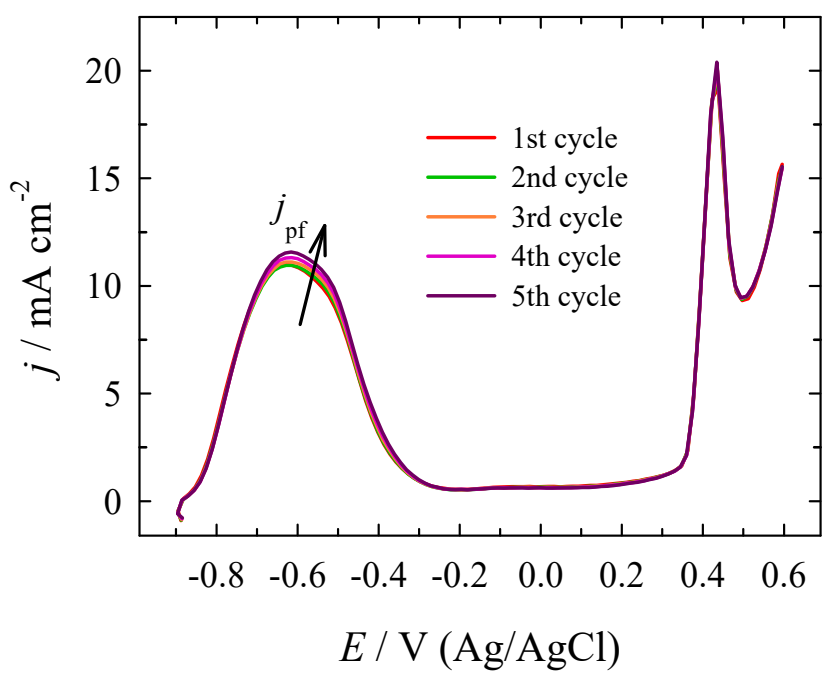

(b)

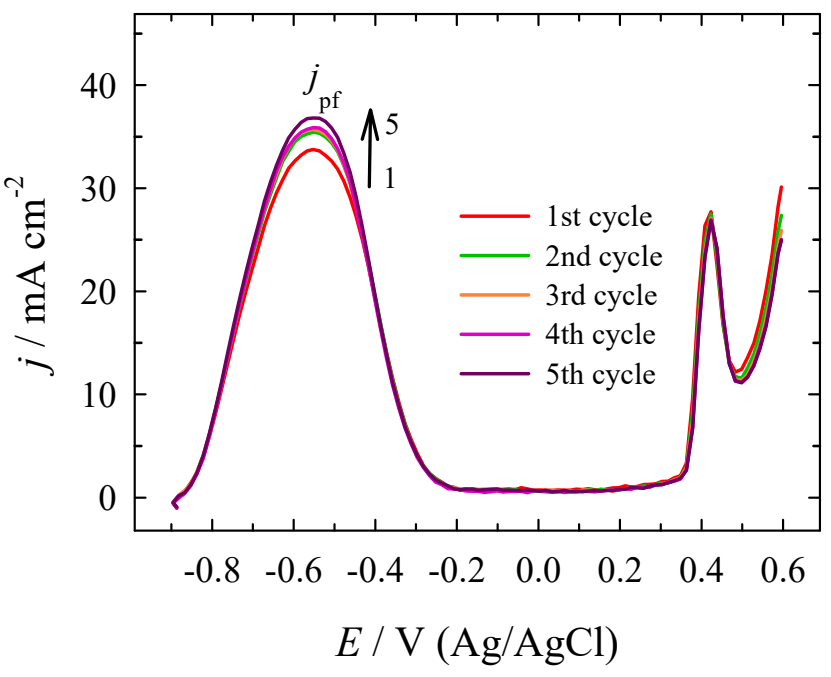

(d)

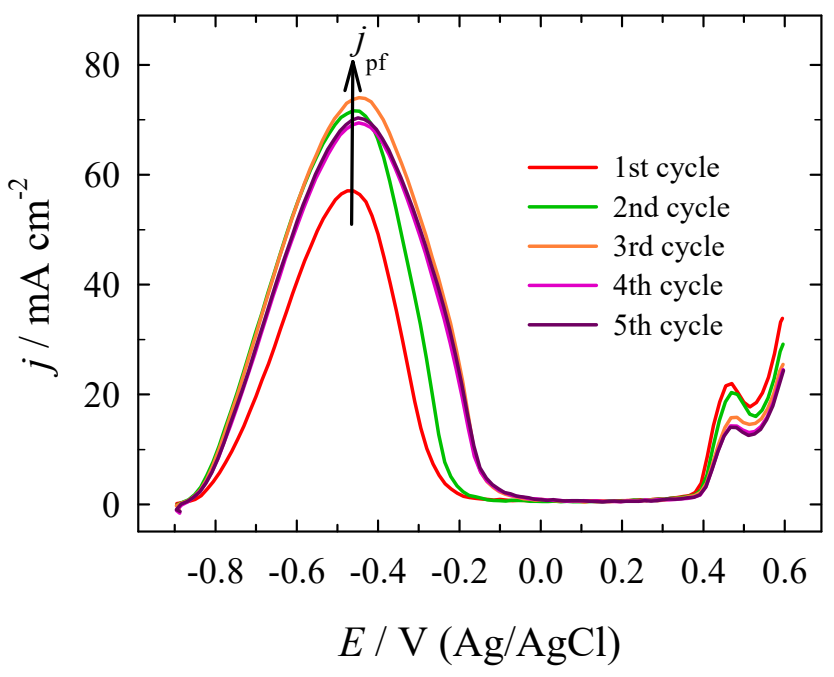

(f)

Figure 5. Positive-going potential scans of $\mathrm{PtNi} / \mathrm{Ni}_{\text {foam }}$ recorded at anodic potential limit of +0.2 $(\mathbf{a}, \mathbf{c}, \mathbf{e})$ and $+0.6 \mathrm{~V}(\mathbf{b}, \mathbf{d}, \mathbf{f})$ in a $1 \mathrm{M} \mathrm{NaOH}$ solution, containing $0.1(\mathbf{a}, \mathbf{b}), 0.3(\mathbf{c}, \mathbf{d})$ and $0.5(\mathbf{e}, \mathbf{f}) \mathrm{M} \mathrm{FA}$, at a scan rate of $50 \mathrm{mV} \mathrm{s}^{-1}$. 
FO improves with increasing (more positive) $E_{\mathrm{ra}}$ because of the impact of the oxophilic transition metal component in the catalyst composition, which involves the potential region in which the $\mathrm{Ni}(\mathrm{OH}) / \mathrm{NiOOH}$ surface transformation takes place and provides an additional quantity of oxygen-containing species at low potentials, which contributes to the oxidation of adsorbed $\mathrm{CO}$, thus decreasing the catalytic poisoning of the catalyst. In general, nickel hydroxide nanostructures play a crucial role in facilitating the dissociative adsorption of water molecules in alkaline media and the subsequent oxidative removal of carbonaceous poisons from neighboring platinum sites [33-35].

The electrocatalytic activity of the investigated catalysts toward FO on FA concentrations is shown in Figure 6. The insets in Figure 6a,b represent the linear relationship between $j_{\text {peak }}$ and $C_{\mathrm{FA}}$, indicating the irreversible electrochemical process kinetics on both $\mathrm{Pt}$ and $\mathrm{PtNi} / \mathrm{Ni}_{\text {foam }}$ catalysts [73]. Moreover, the peak potential slightly shifted to the positive potential values with increasing FA concentration (Figure $6 a, b$ ). The reaction order of FO oxidation was determined by the slopes of $\ln j_{\text {peak }}$ vs. $\ln \mathrm{C}_{\mathrm{FA}}$ (Figure $6 \mathrm{c}$ ) using Equation (2) [73].

$$
j_{\text {peak }}=z C^{\beta} \text { FA }
$$

where $j_{\text {peak }}$ is the peak current density $\left(\mathrm{mA} \mathrm{cm}^{-2}\right), z$ is a constant, $C$ refers to the FA concentration (mol L ${ }^{-1}$ ), and $\beta$ the reaction order concerning $C_{\mathrm{FA}}$. The value of $\beta$ is obtained as 1.11 on the $\mathrm{PtNi} / \mathrm{Ni}_{\text {foam }}$ catalyst and 1.19 on the bare Pt electrode (Figure $6 \mathrm{c}$ ). The determined values corresponded to a first-order reaction.

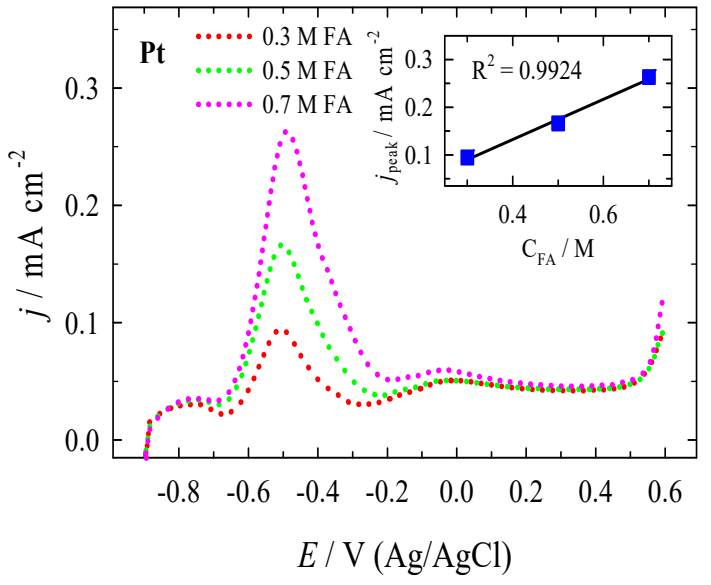

(a)

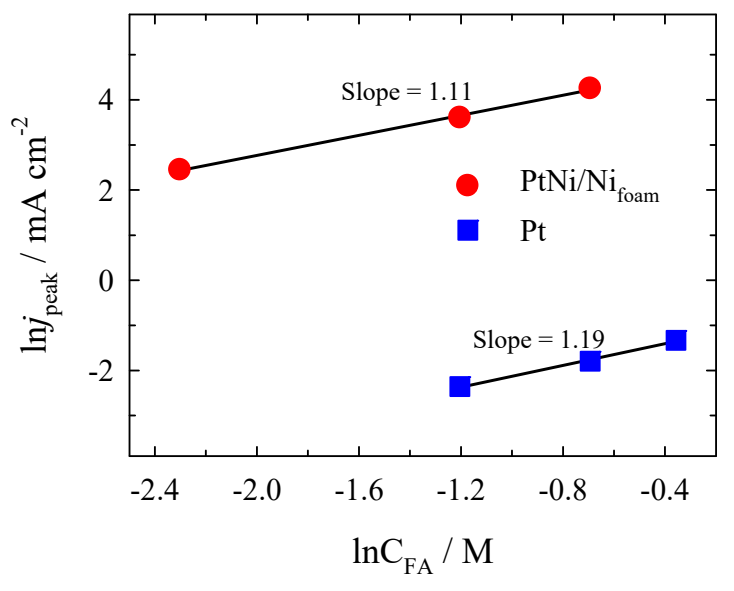

(c)

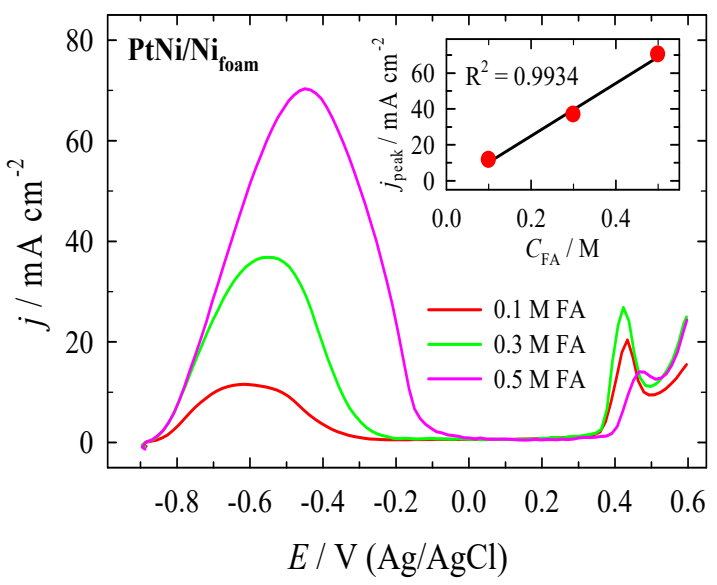

(b)

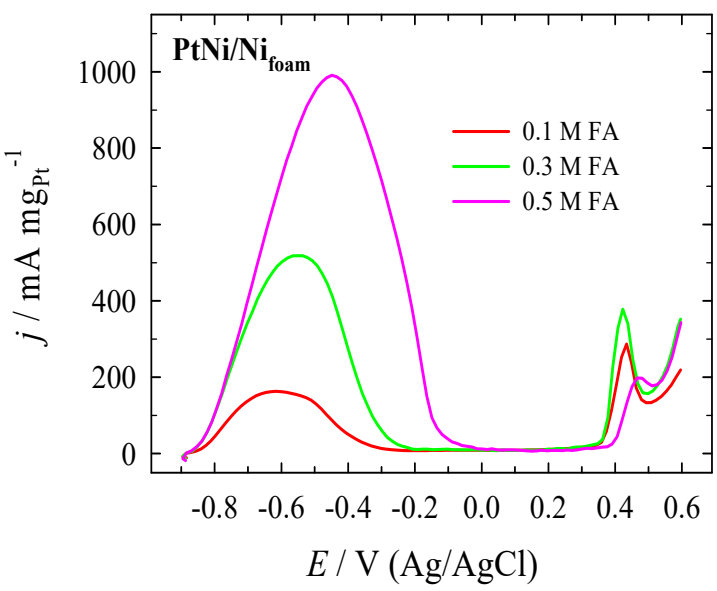

(d)

Figure 6. Positive-going potential scans of $\mathrm{Pt}(\mathbf{a})$ and $\mathrm{PtNi} / \mathrm{Ni}_{\text {foam }}(\mathbf{b})$ for different $\mathrm{FA}$ concentrations with the corresponding $j_{\text {peak }}$ vs. $E$ (the insets) and $\ln j_{\text {peak }}$ vs. $\ln C_{\mathrm{FA}}$ (c). (d) The current density peak values normalized with reference to the $\mathrm{Pt}$ loading for $\mathrm{PtNi} / \mathrm{Ni}_{\text {foam }}$. 
Nevertheless, increasing the FA concentration from 0.3 to $0.5 \mathrm{M}$ led to a ca. 1.8-times increase in $j_{\mathrm{pf}}$ on both catalysts (Figure 6a,b). However, at all FA concentrations, the $j_{\mathrm{pf}}$ on $\mathrm{PtNi} / \mathrm{Ni}_{\text {foam }}$ notably outperforms those on the bare Pt electrode. This result was more than ca. 390-420 times higher in alkaline media on $\mathrm{PtNi} / \mathrm{Ni}_{\text {foam }}$ than on bare Pt. The onset potential of the $\mathrm{PtNi} / \mathrm{Ni}_{\text {foam }}$ (ca. $-0.9 \mathrm{~V}$ ) electrode shifted significantly to a more negative potential region than that of the bare Pt electrode (ca. $-0.7 \mathrm{~V})$. The large difference in $E_{\text {onset }}$ indicates higher $\mathrm{PtNi} / \mathrm{Ni}_{\text {foam }}$ electrocatalytic activity than that of $\mathrm{Pt}$. Moreover, the obtained characteristics of the $\mathrm{PtNi} / \mathrm{Ni}_{\text {foam }}$ catalyst are consistent with those of the state-ofthe-art PGM catalysts for formate oxidation. A comparison of their properties with those of Pt-and Pt-based electrocatalysts used for formate oxidation in alkaline media is presented in Table 5. The results reveal that the developed $\mathrm{PtNi} / \mathrm{Ni}_{\text {foam }}$ catalyst is competitive with state-of-the-art PGM catalysts and outperforms them in many cases. Such favorable results are attributed to the synergy between the $\mathrm{Pt}$ and the Ni-coated porous structure of the $\mathrm{Ni}_{\text {foam }}$ substrate, which prevented the accumulation of incompletely oxidized carbonaceous species $\left(\mathrm{CO}_{\mathrm{ads}}\right)$, directing the $\mathrm{FO}$ reaction toward the dehydrogenation pathway.

Table 5. Comparison of Pt and the Pt-based electrocatalysts for formic acid/formate oxidation at ambient conditions in an alkaline media with respect to the onset potential ( $\left.E_{\text {onset }}\right)$ and maximum current density ( $I_{\max }$, normalized by electrode geometric area) obtained on anodic peaks (at a peak potential $\left.\left(E_{\text {peak }}\right)\right)$. The data are adopted from $[4,8,9,11,12,14,22,70,74-77]$.

\begin{tabular}{|c|c|c|c|c|}
\hline Catalyst & Conditions of Experiment & $\begin{array}{c}E_{\text {onset }} \\
\text { (V vs. RHE) }\end{array}$ & $\begin{array}{c}I_{\text {max }}\left(\mathrm{mA} \mathrm{cm}^{-2}\right) \\
\text { at } E_{\text {peak }}(\mathrm{V} \text { vs. } \\
\text { RHE })\end{array}$ & Ref. \\
\hline Pt disk & $\begin{array}{c}0.2 \mathrm{M} \mathrm{HCOONa}+1 \mathrm{M} \mathrm{NaOH}^{\mathrm{NaOH}} \\
(\mathrm{pH} \approx 14.0) 20 \mathrm{mV} \mathrm{s}^{-1}\end{array}$ & +0.3 & $\begin{array}{c}0.1 \mathrm{~mA} \mathrm{~cm}^{-2} \\
(+0.5 \mathrm{~V} \text { vs. RHE) }\end{array}$ & [19] \\
\hline Pt disk & $\begin{array}{c}0.4 \mathrm{M} \mathrm{HCOO}^{-}+1 \mathrm{M} \mathrm{KNO}_{3} \\
\left(\mathrm{pH} \mathrm{13)} 5 \mathrm{mV} \mathrm{s}^{-1}\right.\end{array}$ & +0.5 & $\begin{array}{c}3.1 \mathrm{~mA} \mathrm{~cm}^{-2} \\
\text { (+1.1 V vs. RHE) }\end{array}$ & [74] \\
\hline $\begin{array}{c}\text { Pt } \\
\text { nanoparticles } \\
(\text { Pt black })\end{array}$ & $\begin{array}{l}0.5 \mathrm{M} \mathrm{HCOOK}+0.5 \mathrm{M} \mathrm{KOH} \\
(\mathrm{pH} \approx 13.7) 50 \mathrm{mV} \mathrm{s}^{-1}\end{array}$ & +0.2 & $\begin{array}{c}0.2 \mathrm{~mA} \mathrm{~cm}^{-2} \\
(+0.5 \mathrm{~V} \text { vs. } \mathrm{RHE})\end{array}$ & {$[70]$} \\
\hline $\begin{array}{c}\operatorname{Pt}(40 \%) / \\
\text { Vulcan carbon }\end{array}$ & $\begin{array}{l}1 \mathrm{M} \mathrm{HCOOK}+1 \mathrm{M} \mathrm{KOH} \\
(\mathrm{pH} \approx 14.0) 20 \mathrm{mV} \mathrm{s}^{-1}\end{array}$ & +0.4 & $\begin{array}{l}14.6 \mathrm{~mA} \mathrm{~cm}^{-2} \\
(+0.6 \mathrm{~V} \text { vs. } \mathrm{RHE})\end{array}$ & [22] \\
\hline $\mathrm{Pt}(50 \%) / \mathrm{C}$ & $\begin{array}{c}0.5 \mathrm{M} \mathrm{HCOOH}+0.5 \mathrm{M} \mathrm{KOH} \\
(\mathrm{pH} \approx 13.7) 50 \mathrm{mV} \mathrm{s}^{-1}\end{array}$ & +0.8 & $\begin{array}{l}33.9 \mathrm{~mA} \mathrm{~cm}^{-2} \\
(+1.2 \mathrm{~V} \text { vs. RHE})\end{array}$ & {$[11]$} \\
\hline $\begin{array}{c}\text { PtAg alloy } \\
\text { nanoballoon } \\
\text { nanoassembly }\end{array}$ & $\begin{array}{l}1 \mathrm{M} \mathrm{HCOOK}+1 \mathrm{M} \mathrm{KOH} \\
(\mathrm{pH} \approx 14.0) 50 \mathrm{mV} \mathrm{s}^{-1}\end{array}$ & +0.2 & $\begin{array}{l}32.6 \mathrm{~mA} \mathrm{~cm}^{-2} \\
(+0.7 \mathrm{~V} \text { vs. } \mathrm{RHE})\end{array}$ & [17] \\
\hline Pd black & $\begin{array}{c}0.5 \mathrm{M} \mathrm{HCOOH}+0.5 \mathrm{M} \mathrm{KOH} \\
(\mathrm{pH} \approx 13.7) 50 \mathrm{mV} \mathrm{s}^{-1}\end{array}$ & +0.8 & $\begin{array}{l}27.3 \mathrm{~mA} \mathrm{~cm}^{-2} \\
(+1.2 \mathrm{~V} \text { vs. } \mathrm{RHE})\end{array}$ & [11] \\
\hline $\mathrm{Pd} / \mathrm{C}$ & $\begin{array}{l}1 \mathrm{M} \mathrm{HCOOK}+1 \mathrm{M} \mathrm{KOH} \\
(\mathrm{pH} \approx 14.0) 50 \mathrm{mV} \mathrm{s}^{-1}\end{array}$ & +0.1 & $\begin{array}{l}108.8 \mathrm{~mA} \mathrm{~cm}^{-2} \\
(+0.7 \mathrm{~V} \text { vs. RHE})\end{array}$ & [4] \\
\hline $\begin{array}{l}\text { Pd }(20 \%)-\mathrm{H} / \text { Vulcan } \\
\text { carbon }\end{array}$ & $\begin{array}{l}0.5 \mathrm{M} \mathrm{HCOOK}+1 \mathrm{M} \mathrm{KOH} \\
\quad(\mathrm{pH} \approx 14.0) 20 \mathrm{mV} \mathrm{s}^{-1}\end{array}$ & +0.2 & $\begin{array}{l}71.0 \mathrm{~mA} \mathrm{c} \mathrm{cm}^{-2} \\
(+0.8 \mathrm{~V} \text { vs. } \mathrm{RHE})\end{array}$ & [76] \\
\hline $\mathrm{Pd}(20 \%) / \mathrm{C}$ & $\begin{array}{l}1 \mathrm{M} \mathrm{HCOONa}+1 \mathrm{M} \mathrm{NaOH} \\
(\mathrm{pH} \approx 14.0) 20 \mathrm{mV} \mathrm{s}^{-1}\end{array}$ & +0.2 & $\begin{array}{c}40.0 \mathrm{~mA} \mathrm{~cm}^{-2} \\
(+0.8 \mathrm{~V} \text { vs. RHE})\end{array}$ & [75] \\
\hline $\begin{array}{l}\text { Pd }(25 \%) / \text { Vulcan } \\
\text { carbon }\end{array}$ & $\begin{array}{l}1 \mathrm{M} \mathrm{HCOOK}+1 \mathrm{M} \mathrm{KOH} \\
(\mathrm{pH} \approx 14.0) 50 \mathrm{mV} \mathrm{s}^{-1}\end{array}$ & +0.2 & $\begin{array}{c}4.6 \mathrm{~mA} \mathrm{~cm}^{-2} \\
(+0.7 \mathrm{~V} \text { vs. RHE) }\end{array}$ & [8] \\
\hline $\begin{array}{l}\text { Pd }(40 \%) / \text { Vulcan } \\
\text { carbon }\end{array}$ & $\begin{array}{l}1 \mathrm{M} \mathrm{HCOOK}+1 \mathrm{M} \mathrm{KOH} \\
(\mathrm{pH} \approx 14.0) 20 \mathrm{mV} \mathrm{s}^{-1}\end{array}$ & +0.2 & $\begin{array}{l}102.0 \mathrm{~mA} \mathrm{~cm}^{-2} \\
(+1.0 \mathrm{~V} \text { vs. RHE})\end{array}$ & [22] \\
\hline $\begin{array}{l}\text { Pd/Vulcan } \\
\text { carbon }\end{array}$ & $\begin{array}{l}1 \mathrm{M} \mathrm{HCOOK}+1 \mathrm{M} \mathrm{KOH} \\
(\mathrm{pH} \approx 14.0) 50 \mathrm{mV} \mathrm{s}^{-1}\end{array}$ & +0.4 & $\begin{array}{c}23.0 \mathrm{~mA} \mathrm{~cm}^{-2} \\
(+0.8 \mathrm{~V} \text { vs. } \mathrm{RHE})\end{array}$ & [77] \\
\hline $\begin{array}{l}\text { Pd }(20 \%) / \text { Reduced } \\
\text { graphene oxide }\end{array}$ & $\begin{array}{c}1 \mathrm{M} \mathrm{HCOONa}+1 \mathrm{M} \mathrm{NaOH}^{\mathrm{HCOOH}} \\
(\mathrm{pH} \approx 14.0) 20 \mathrm{mV} \mathrm{s}^{-1}\end{array}$ & +0.2 & $\begin{array}{l}57.0 \mathrm{~mA} \mathrm{~cm}^{-2} \\
(+0.8 \mathrm{~V} \text { vs. } \mathrm{RHE})\end{array}$ & [75] \\
\hline
\end{tabular}


Table 5. Cont.

\begin{tabular}{|c|c|c|c|c|}
\hline Catalyst & Conditions of Experiment & $\begin{array}{c}E_{\text {onset }} \\
\text { (V vs. RHE) }\end{array}$ & $\begin{array}{c}I_{\text {max }}\left(\mathrm{mA} \mathrm{cm}^{-2}\right) \\
\text { at } E_{\text {peak }}(\mathrm{V} \text { vs. } \\
\text { RHE })\end{array}$ & Ref. \\
\hline $\mathrm{Pd}_{54} \mathrm{Ag}_{46}$ (core-shell) & $\begin{array}{c}1 \mathrm{M} \mathrm{HCOOK}+1 \mathrm{M} \mathrm{KOH}^{-} \\
(\mathrm{pH} \approx 14.0) 50 \mathrm{mV} \mathrm{s}^{-1}\end{array}$ & +0.2 & $\begin{array}{c}31.0 \mathrm{~mA} \mathrm{~cm}^{-2} \\
(+0.7 \mathrm{~V} \text { vs. RHE) }\end{array}$ & [8] \\
\hline $\begin{array}{c}\mathrm{Pd}_{70} \mathrm{Cu}_{30} / \text { Vulcan } \\
\text { carbon }\end{array}$ & $\begin{array}{l}1 \mathrm{M} \mathrm{HCOOK}+1 \mathrm{M} \mathrm{KOH}^{-} \\
(\mathrm{pH} \approx 14.0) 50 \mathrm{mV} \mathrm{s}^{-1}\end{array}$ & +0.2 & $\begin{array}{c}4.3 \mathrm{~mA} \mathrm{~cm}^{-2} \\
(+0.6 \mathrm{~V} \text { vs. RHE) }\end{array}$ & \multirow{4}{*}[12]{} \\
\hline $\begin{array}{l}\mathrm{Pd}_{72} \mathrm{Ce}_{28} / \text { Vulcan } \\
\text { carbon }\end{array}$ & $\begin{array}{l}1 \mathrm{M} \mathrm{HCOOK}+1 \mathrm{M} \mathrm{KOH} \\
(\mathrm{pH} \approx 14.0) 50 \mathrm{mV} \mathrm{s}^{-1}\end{array}$ & +0.1 & $\begin{array}{c}19.4 \mathrm{~mA} \mathrm{~cm}^{-2} \\
(+0.6 \mathrm{~V} \text { vs. RHE) }\end{array}$ & \\
\hline $\begin{array}{l}\mathrm{Pd}_{2.3} \mathrm{Co} / \text { Vulcan } \\
\text { carbon }\end{array}$ & $\begin{array}{c}1 \mathrm{M} \mathrm{HCOOK}+1 \mathrm{M} \mathrm{KOH} \\
(\mathrm{pH} \approx 14.0) 50 \mathrm{mV} \mathrm{s}^{-1}\end{array}$ & +0.3 & $\begin{array}{c}38.0 \mathrm{~mA} \mathrm{~cm}^{-2} \\
(+0.8 \mathrm{~V} \text { vs. } \mathrm{RHE})\end{array}$ & \\
\hline PdNi/Vulcan carbon & $\begin{array}{l}1 \mathrm{M} \mathrm{HCOOK}+1 \mathrm{M} \mathrm{KOH}^{\mathrm{M}} \\
(\mathrm{pH} \approx 14.0) 50 \mathrm{mV} \mathrm{s}^{-1}\end{array}$ & 0.2 & $\begin{array}{c}74.0 \mathrm{~mA} \mathrm{~cm}^{-2} \\
(+0.8 \mathrm{~V} \text { vs. RHE) }\end{array}$ & \\
\hline PdNi/Ketjen carbon & $\begin{array}{l}1 \mathrm{M} \mathrm{HCOOK}+1 \mathrm{M} \mathrm{KOH}^{-} \\
(\mathrm{pH} \approx 14.0) 50 \mathrm{mV} \mathrm{s}^{-1}\end{array}$ & 0.2 & $\begin{array}{l}117.0 \mathrm{~mA} \mathrm{~cm}^{-2} \\
(+0.8 \mathrm{~V} \text { vs. RHE) }\end{array}$ & {$[77]$} \\
\hline $\begin{array}{l}\mathrm{Pd}_{60} \mathrm{Ag}_{20} \mathrm{Ni}_{20} \\
\text { (alloyed) }\end{array}$ & $\begin{array}{c}1 \mathrm{M} \mathrm{HCOOK}+1 \mathrm{M} \mathrm{KOH}^{-} \\
(\mathrm{pH} \approx 14.0) 50 \mathrm{mV} \mathrm{s}^{-1}\end{array}$ & 0.2 & $\begin{array}{l}99.6 \mathrm{~mA} \mathrm{~cm}^{-2} \\
(+0.8 \mathrm{~V} \text { vs. RHE }\end{array}$ & [9] \\
\hline $\mathrm{Pd}_{2} \mathrm{Ag}_{1}$ aerogel & $\begin{array}{l}0.5 \mathrm{M} \mathrm{HCOOK}+0.5 \mathrm{M} \mathrm{KOH}^{-} \\
\quad(\mathrm{pH} \approx 13.7) 50 \mathrm{mV} \mathrm{s}^{-1}\end{array}$ & 0.2 & $\begin{array}{c}27.5 \mathrm{~mA} \mathrm{~cm}^{-2} \\
(+0.8 \mathrm{~V} \text { vs. RHE) }\end{array}$ & \multirow[t]{2}{*}{ [8] } \\
\hline $\mathrm{Pd}_{2} \mathrm{Ag}_{1} \mathrm{Pt}_{0.25}$ aerogel & $\begin{array}{l}0.5 \mathrm{M} \mathrm{HCOOK}+0.5 \mathrm{M} \mathrm{KOH} \\
(\mathrm{pH} \approx 13.7) 50 \mathrm{mV} \mathrm{s}^{-1}\end{array}$ & 0.1 & $\begin{array}{c}60.0 \mathrm{~mA} \mathrm{~cm}^{-2} \\
(+0.7 \mathrm{~V} \text { vs. } \mathrm{RHE})\end{array}$ & \\
\hline Pd (interstitial B) & $\begin{array}{c}0.5 \mathrm{M} \mathrm{HCOOK}+1 \mathrm{M} \mathrm{KOH} \\
(\mathrm{pH} \approx 14.0) 100 \mathrm{mv} \mathrm{s}^{-1}\end{array}$ & 0.2 & $\begin{array}{c}90 \mathrm{~mA} \mathrm{~cm}^{-2} \\
(+0.8 \mathrm{~V} \text { vs. RHE) }\end{array}$ & {$[14]$} \\
\hline $\begin{array}{l}\text { PdCuPt (hierarchical } \\
\text { zigzag-branched } \\
\text { urchin-like } \\
\text { superstructure }\end{array}$ & $\begin{array}{l}0.5 \mathrm{M} \mathrm{HCOOH}+0.5 \mathrm{M} \mathrm{KOH}^{-1} \\
\quad(\mathrm{pH} \approx 13.7) 50 \mathrm{mV} \mathrm{s}^{-1}\end{array}$ & 0.5 & $\begin{array}{l}102.4 \mathrm{~mA} \mathrm{~cm}^{-2} \\
(+1.2 \mathrm{~V} \text { vs. RHE })\end{array}$ & {$[11]$} \\
\hline $\mathrm{Pt}$ & $\begin{array}{l}0.5 \mathrm{M} \mathrm{HCOOH}+1 \mathrm{M} \mathrm{NaOH}^{-} \\
(\mathrm{pH} \approx 14.0) 50 \mathrm{mV} \mathrm{s}^{-1}\end{array}$ & 0.34 & $\begin{array}{c}0.17 \mathrm{~mA} \mathrm{~cm}^{-2} \\
(+0.53 \mathrm{~V} \text { vs. RHE})\end{array}$ & $\begin{array}{l}\text { Our } \\
\text { work }\end{array}$ \\
\hline $\mathrm{PtNi} / \mathrm{Ni}_{\text {foam }}$ & $\begin{array}{c}0.5 \mathrm{M} \mathrm{HCOOH}+1 \mathrm{M} \mathrm{NaOH} \\
(\mathrm{pH} \approx 14.0) 50 \mathrm{mV} \mathrm{s}^{-1}\end{array}$ & 0.14 & $\begin{array}{c}70.32 \mathrm{~mA} \mathrm{~cm}^{-2} \\
(+0.59 \mathrm{~V} \text { vs. RHE }\end{array}$ & $\begin{array}{l}\text { Our } \\
\text { work }\end{array}$ \\
\hline
\end{tabular}

To evaluate the mass activity of the investigated $\mathrm{PtNi} / \mathrm{Ni}_{\text {foam }}$ catalyst toward $\mathrm{FO}$, the current density values for different FA concentrations in alkaline media were normalized with reference to the $\mathrm{Pt}$ loading for the $\mathrm{PtNi} / \mathrm{Ni}_{\text {foam }}$ catalysts (Figure $6 \mathrm{~d}$ ). The highest FO mass activity of the $\mathrm{PtNi} / \mathrm{Ni}_{\text {foam }}$ catalyst is ca. $990 \mathrm{~mA} \mathrm{mg}_{\mathrm{Pt}}{ }^{-1}$, larger than $\mathrm{Pt} / \mathrm{C}$ (ca. $225 \mathrm{~mA} \mathrm{mg}_{\mathrm{Pt}}{ }^{-1}$ ) [40], $\mathrm{Pt} / \mathrm{C}\left(391.2 \mathrm{~mA} \mathrm{mg}_{\mathrm{Pt}}{ }^{-1}\right.$ ) [11], and $\mathrm{PtSnO}_{2} / \mathrm{C}$ (ca. $600 \mathrm{~mA} \mathrm{mg}_{\mathrm{Pt}}{ }^{-1}$ ) [40].

The stability of the $\mathrm{PtNi} / \mathrm{Ni}_{\text {foam }}$ catalyst was examined by chronoamperometry in 1 $\mathrm{M} \mathrm{NaOH}$ solutions containing 0.1, 0.3, and 0.5 M FA (Figure 7). As illustrated, the FOR current density for the $\mathrm{PtNi} / \mathrm{Ni}_{\text {foam }}$ catalyst was the highest in $0.5 \mathrm{M} \mathrm{FA}+1 \mathrm{M} \mathrm{NaOH}$ media; meanwhile, the current density disappeared completely after only $2000 \mathrm{~s}$ in a solution containing a lower concentration of FA. This indicates that an increase in the FA concentration increases the stability of the $\mathrm{PtNi} / \mathrm{Ni}_{\text {foam }}$ catalyst.

Additionally, the morphological measurements confirmed the stability of the $\mathrm{PtNi} / \mathrm{Ni}_{\text {foam }}$ catalyst. Figure S4 (Supplementary Material) shows an SEM view of a thin Ni layer deposited on the $\mathrm{Ni}_{\text {foam }}$ substrate, using sodium hypophosphite as a reducing agent before the electrochemical deposition of Pt. The Ni layer accurately replicates the threedimensional network structure of the $\mathrm{Ni}_{\text {foam }}$ backbone with micro-open cages and wide flow channels inside them (Figure S4a). The SEM image of the Pt layer on the $\mathrm{Ni} / \mathrm{Ni}_{\text {foam }}$ surface after continuous electrode cycling in $0.5 \mathrm{M} \mathrm{FA}+1 \mathrm{M} \mathrm{NaOH}$ in the potential region from -0.9 to $+0.6 \mathrm{~V}$ vs. $\mathrm{Ag} / \mathrm{AgCl}$ is displayed in Figure S4b,c (Supplementary Material). Bright spots of Pt the size of about $12-18 \mathrm{~nm}$ are evenly distributed over the entire $\mathrm{Ni} / \mathrm{Ni} i_{\text {foam }}$ surface, as depicted in Figure S4c (Supplementary Material). The presence of Pt is further supported by EDX data indicating that the amount of deposited $\mathrm{Pt}$ in the $\mathrm{PtNi} / \mathrm{Ni}_{\text {foam }}$ catalyst reaches $39.63 \mathrm{at} \%$. Meanwhile, the amount of $\mathrm{Ni}$ is $60.37 \mathrm{at} \%$. Continuous cycling in 
FA solution does not significantly change the surface morphology of the catalyst, indicating the high stability and activity of the $\mathrm{PtNi} / \mathrm{Ni}_{\text {foam }}$ catalyst.



Figure 7. CA data for the $\mathrm{PtNi} / \mathrm{Ni}_{\text {foam }}$ catalyst were recorded in a $1 \mathrm{M} \mathrm{NaOH}$ solution containing 0.1 , 0.3 and $0.5 \mathrm{M}$ FA, at a constant potential value $E=-0.6 \mathrm{~V}$ for $2600 \mathrm{~s}$.

To confirm the better tolerance toward catalyst poisoning by adsorbed carbonaceous species on the $\mathrm{PtNi} / \mathrm{Ni}_{\text {foam }}$ catalyst compared to that on the bare Pt electrode, the $\mathrm{CO}$ stripping parameters were adjusted. The obtained data are shown in Figure 8.



(a)

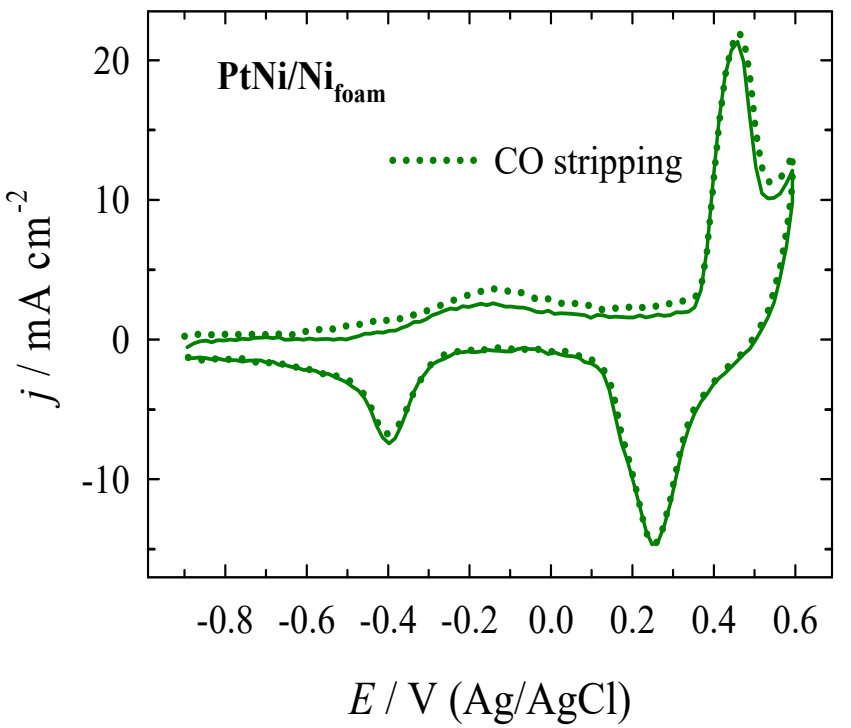

(b)

Figure 8. $\mathrm{CVs}$ for the oxidative $\mathrm{CO}$ stripping from the $\mathrm{Pt}(\mathbf{a})$ and $\mathrm{PtNi} / \mathrm{Ni}_{\text {foam }}(\mathbf{b})$ catalysts surface in $1 \mathrm{M} \mathrm{NaOH}$ at a scan rate of $50 \mathrm{mV} \mathrm{s}^{-1}$. CO was adsorbed at $-0.9 \mathrm{~V}$ from $1 \mathrm{M} \mathrm{NaOH}$ for $15 \mathrm{~min}$; a potential sweep was carried out in an $\mathrm{N}_{2}$-saturated solution.

A prominent $\mathrm{CO}_{\mathrm{ads}}$ oxidation current density peak was observed during the positive potential scan of the bare Pt electrode in $1 \mathrm{M} \mathrm{NaOH}$. Concurrently, the same peak for the $\mathrm{PtNi} / \mathrm{Ni}_{\text {foam }}$ catalyst completely disappeared, indicating that the $\mathrm{PtNi} / \mathrm{Ni}_{\text {foam }}$ catalyst has almost total CO poisoning tolerance in an alkaline medium, unlike bare Pt. The results indicate that the oxidative removal of carbonaceous poisoning species from adjacent $\mathrm{Pt}$ sites by $\mathrm{Ni}(\mathrm{OH})_{2}$ was facilitated by the presence of a stable and reversible $\mathrm{Ni}$ (II)/ $\mathrm{Ni}$ (III) 
redox transformation in alkaline media, as shown in Equation (1). The improvement in the formate oxidation reaction could be explained by the presence of a Ni-oxy species that can act as catalytic mediators via the abovementioned reaction by facilitating a charge transfer during the direct oxidation of formate to $\mathrm{CO}_{2}$, simultaneously oxidizing $\mathrm{CO}$ at a low potential throughout subsequent reactions [32,42,43].

\section{Conclusions}

A promising novel binary catalyst composed of a Pt-modified $\mathrm{Ni}$ layer coated on $\mathrm{Ni}_{\text {foam }}$ was proposed for efficient formate oxidation in an alkaline medium. The $\mathrm{PtNi} / \mathrm{Ni}_{\text {foam }}$ catalyst was found to have a significantly high FO mass activity $\left(990 \mathrm{~mA} \mathrm{mg}_{\mathrm{Pt}}{ }^{-1}\right)$. Moreover, it exhibited enhanced electrocatalytic activity toward formate oxidation via a direct pathway in an alkaline medium, unlike the pure Pt electrode. The prepared $\mathrm{PtNi} / \mathrm{Ni}_{\text {foam }}$ catalyst was tolerant to $\mathrm{CO}$ poisoning in an alkaline medium and demonstrated high poison removal ability. It shows rather negative onset potential on the bare $\mathrm{Pt}$. The significant improvement in the $E_{\text {onset }}$ to ca. $-0.9 \mathrm{~V}$ for $\mathrm{PtNi} / \mathrm{Ni}_{\text {foam }}$, compared to ca. $-0.7 \mathrm{~V}$ for bare $\mathrm{Pt}$, indicates that the $\mathrm{PtNi} / \mathrm{Ni}_{\text {foam }}$ electrode is competitive with the benchmark $\mathrm{Pt}$ and Pt-based electrocatalysts for formate oxidation in alkaline media. The improvement in electrocatalytic activity is a result of synergy between $\mathrm{Pt}$ and the porous structure of the $\mathrm{Ni}$-oxy species layer on the $\mathrm{Ni}_{\text {foam }}$, which is intended to assist in the oxidative removal of the accumulated carbonaceous species from the surface by acting as a catalytic mediator for charge transfer in the oxidation process.

The PtNi/ $\mathrm{Ni}_{\text {foam }}$ catalyst appears to be a promising anode material for application in direct liquid FA fuel cells.

Supplementary Materials: The following supporting information can be downloaded at: https:/ / www.mdpi.com/article/10.3390/cryst12030362/s1, Figure S1: CVs of Pt (dotted lines) and PtNi/Ni $\mathrm{foam}_{\text {f }}$ (blue solid line) recorded in a $0.5 \mathrm{M} \mathrm{H}_{2} \mathrm{SO}_{4}$ solution at a scan rate of $50 \mathrm{mV} \mathrm{s}^{-1}$; Figure S2: CVs at the Pt electrode recorded in a $1 \mathrm{M} \mathrm{NaOH}$ solution (red solid line) and that containing $0.3,0.5$, and 0.7 M FA (anodic potential scan—solid lines and cathodic potential scan-dotted lines) at a scan rate $50 \mathrm{mV} \mathrm{s}^{-1}$; Figure S3: Negative-going potential CVs of $\mathrm{PtNi} / \mathrm{Ni}_{\text {foam }}$ recorded at anodic potential limit of $0.2(\mathrm{a}, \mathrm{c}, \mathrm{e})$ and $0.6 \mathrm{~V}(\mathrm{~b}, \mathrm{~d}, \mathrm{f})$ in a $1 \mathrm{M} \mathrm{NaOH}$ solution containing $0.1(\mathrm{a}, \mathrm{b}), 0.3(\mathrm{c}, \mathrm{d})$, and $0.5(\mathrm{e}, \mathrm{f})$ $\mathrm{M} F A$ at a scan rate of $50 \mathrm{mV} \mathrm{s}^{-1}$; Figure $\mathrm{S} 4$ : SEM views of as-prepared $\mathrm{Ni}_{\text {foam }}$ substrate coated by a Ni layer (a) and PtNi/Nifoam electrode at different magnifications $(b, c)$ after continuous cycling in $0.5 \mathrm{M} \mathrm{FA}+1 \mathrm{M} \mathrm{NaOH}$ in a potential region from -0.9 to $+0.6 \mathrm{~V}$ vs. $\mathrm{Ag} / \mathrm{AgCl}$ at a scan rate of $50 \mathrm{mV} \mathrm{s}^{-1}$. (d) The corresponding EDX spectra for $\mathrm{PtNi} / \mathrm{Ni}_{\text {foam }}$ electrode.

Author Contributions: This study was conducted through the contributions of all authors. Conceptualization, L.T.-T., A.N. and E.N.; Methodology, D.U., V.K. and V.J.; Investigation, B.Š., A.B. and A.Z.; formal analysis, B.Š. and A.B.; Validation, A.Z., D.Š.; Writing-Original Draft Preparation, A.N. and D.Š.; Writing-Review and Editing, L.T.-T. and E.N.; Visualization, D.U., V.K. and V.J. All authors have read and agreed to the published version of the manuscript.

Funding: This research was funded by European Union Structural Funds project "Development of Doctoral Studies" under grant No. 09.3.3.-ESFA-V-711-01-0001.

Institutional Review Board Statement: Not applicable.

Informed Consent Statement: Not applicable.

Data Availability Statement: Not applicable.

Conflicts of Interest: The authors declare no conflict of interest.

\section{References}

1. Fang, Z.; Chen, W. Recent advances in formic acid electro-oxidation: From the fundamental mechanism to electrocatalysts. Nanoscale Adv. 2021, 3, 94-105. [CrossRef]

2. Folkman, S.J.; González-Cobos, J.; Giancola, S.; Sánchez-Molina, I.; Galán-Mascarós, J.R. Benchmarking Catalysts for Formic Acid/Formate Electrooxidation. Molecules 2021, 26, 4756. [CrossRef] [PubMed] 
3. Shen, T.; Zhang, J.; Chen, K.; Deng, S.; Wang, D. Recent Progress of Palladium-Based Electrocatalysts for the Formic Acid Oxidation Reaction. Energy Fuels 2020, 34, 9137-9153. [CrossRef]

4. An, L.; Chen, R. Direct formate fuel cells: A review. J. Power Sources 2016, 320, 127-139. [CrossRef]

5. Uwitonze, N.; Chen, Y.X. The study of Pt and Pd based anode catalysis for formic acid fuel cell. Chem. Sci. J. 2017, 8, 167. [CrossRef]

6. Mao, H.; Huang, T.; Yu, A. Electrochemical surface modification on CuPdAu/C with extraordinary behavior toward formic acid/ formate oxidation. Int. J. Hydrogen Energy 2016, 41, 13190-13196. [CrossRef]

7. Ding, J.; Liu, Z.; Liu, X.; Liu, J.; Deng, Y.; Han, X.; Zhong, C.; Hu, W. Mesoporous decoration of freestanding palladium nanotube arrays boosts the electrocatalysis capabilities toward formic acid and formate oxidation. Adv. Energy Mater. 2019, 9, 1900955. [CrossRef]

8. Wang, J.; Chen, F.; Jin, Y.; Guo, L.; Gong, X.; Wanga, X.; Johnston, R.L. In situ high-potential-driven surface restructuring of ternary AgPd-Pt dilute aerogels with record-high performance improvement for formate oxidation electrocatalysis. Nanoscale 2019, 11, 14174-14185. [CrossRef]

9. Wang, Q.; Chen, F.; Tang, Q.; Guo, L.; Gebremarian, T.; Jin, T.; Liu, H.; Kou, B.; Li, Z.; Bian, W. Transition from core-shell to janus segregation pattern in AgPd nanoalloy by Ni doping for the formate oxidation. Appl. Catal. B Environ. 2020, $270,118861$. [CrossRef]

10. Wang, Q.; Chen, F.; Guo, L.; Jin, T.; Liu, H.; Wang, X.; Gong, X.; Liu, Y. Nanoalloying effects on the catalytic activity of the formate oxidation reaction over AgPd and AgCuPd aerogels. J. Mater. Chem. A 2019, 7, 16122-16135. [CrossRef]

11. Chen, Y.; Niu, H.; Feng, Y.; Wu, J.; Wang, A.; Huang, H.; Feng, J. Three-dimensional hierarchical urchin-like PdCuPt nanoassembles with zigzag branches: A highly efficient and durable electrocatalyst for formic acid oxidation reaction. Appl. Surf. Sci. 2020, 510, 145480. [CrossRef]

12. Tang, Q.; Chen, F.; Jin, T.; Guo, L.; Wang, Q.; Liu, H. Alloying in inverse $\mathrm{CeO}_{2} / \mathrm{Pd}$ nanoparticles to enhance the electrocatalytic activity for the formate oxidation reaction. J. Mater. Chem. A 2019, 7, 22996-23007. [CrossRef]

13. Hwang, E.; Park, H.; Kim, H.; Ahn, S.H.; Kim, S.K. Electrochemically fabricated Pd-In catalysts for carbon dioxide- formate/formic acid inter-conversion. Bull. Korean Chem. Soc. 2017, 38, 607-613. [CrossRef]

14. Hong, S.; Chung, S.; Park, J.; Hwang, J.; Lee, C.; Uhm, S.; Bong, S.; Lee, J. Contribution of interstitial boron in a boron-incorporated palladium catalyst toward formate oxidation in an alkaline direct formate fuel cell. ACS Catal. 2021, 11, 4722-4729. [CrossRef]

15. Yang, L.; Li, G.; Chang, J.; Ge, J.; Liu, C.; Vladimir, F.; Wang, G.; Jin, Z.; Xing, W. Modification of palladium nanocrystals with single atom platinum via an electrochemical self-catalysis strategy for efficient formic acid electrooxidation. Appl. Catal. B 2020, 260, 118200. [CrossRef]

16. da Silva, S.G.; Silva, J.C.M.; Buzzo, G.S.; Neto, A.O.; Assumpção, M.H.M.T. Use of PtAu/C electrocatalysts toward formate oxidation: Electrochemical and fuel cell considerations. Mater. Renew. Sustain. Energy 2016, 5, 15. [CrossRef]

17. Han, S.-H.; Liu, H.-M.; Bai, J.; Tian, X.L.; Xia, B.Y.; Zeng, J.-H.; Jiang, J.-X.; Chen, Y. Platinum-silver alloy nanoballoon nanoassemblies with super catalytic activity for the formate electrooxidation. ACS Appl. Energy Mater. 2018, 1, 1252-1258. [CrossRef]

18. Yang, Z.; Wang, Y.; Dong, T.; Yuan, X.; Lv, L.; Wei, X.; Wang, J. Formate: A possible replacement for formic acid in fuel cells. Austral. J. Chem. 2017, 70, 757-763. [CrossRef]

19. John, J.; Wang, H.; Rus, E.D.; Abruna, H.D. Mechanistic studies of formate oxidation on platinum in alkaline medium. J. Phys. Chem. C 2012, 116, 5810-5820. [CrossRef]

20. Joo, J.; Uchida, T.; Cuesta, A.; Koper, M.T.M.; Osawa, M. Importance of acid-base equilibrium in electrocatalytic oxidation of formic acid on platinum. J. Am. Chem. Soc. 2013, 135, 9991-9994. [CrossRef]

21. Li, Y.; Feng, Y.; Sun, X.; He, Y. A sodium-ion-conducting direct formate fuel cell: Generating electricity and producing base. Angew. Chem. 2017, 129, 5828-5831. [CrossRef]

22. Yu, X.; Manthiram, A. Catalyst-selective, scalable membraneless alkaline direct formate fuel cells. Appl. Catal. B Environ. 2015, 165, 63-67. [CrossRef]

23. Themsirimongkon, S.; Pongpichayakul, N.; Fang, L.; Jakmunee, J.; Saipanya, S. New catalytic designs of Pt on carbon nanotubenickel-carbon black for enhancement of methanol and formic acid oxidation. J. Electroanal. Chem. 2020, 876, 114518. [CrossRef]

24. Kiani, M.; Zhang, J.; Luo, Y.; Chen, Y.; Chen, J.; Fan, J.; Wang, G.; Wang, R. Facile synthesis and enhanced catalytic activity of electrochemically dealloyed platinum-nickel nanoparticles towards formic acid electro-oxidation. J. Energy Chem. 2019, 35, 9-16. [CrossRef]

25. Zhang, B.-W.; Zhang, Z.-C.; Liao, H.-G.; Gong, Y.; Gu, L.; Qu, X.-M.; You, L.-X.; Liu, S.; Huang, L.; Tian, X.-C.; et al. Tuning Pt-skin to Ni-rich surface of $\mathrm{Pt}_{3} \mathrm{Ni}$ catalysts supported on porous carbon for enhanced oxygen-reduction reaction and formic electro-oxidation. Nano Energy 2016, 19, 198-209. [CrossRef]

26. Pei, A.; Ruan, L.; Liu, B.; Chen, W.; Lin, S.; Chen, B.; Liu, Y.; Zhu, L.H.; Chen, B.H. Ultra-low Au decorated PtNi alloy nanoparticles on carbon for high-efficiency electro-oxidation of methanol and formic acid. Int. J. Hydrogen Energy 2020, 45, 22893-22905. [CrossRef]

27. Lee, J.; Yoo, J.K.; Lee, H.; Kim, S.H.; Sohn, Y.; Rhee, C.K. Formic acid oxidation on Pt deposit model catalysts on Au: Single-layered Pt deposits, plateau-type Pt deposits, and conical Pt deposits. Electrochim. Acta 2019, 310, 38-44. [CrossRef]

28. Perales-Rondón, J.V.; Ferre-Vilaplana, A.; Feliu, J.M.; Herrero, E. Oxidation mechanism of formic acid on the bismuth adatommodified Pt(111) surface. J. Amer. Chem. Soc. 2014, 136, 13110-13113. [CrossRef] 
29. Wang, C.Y.; Yu, Z.-Y.; Li, G.; Song, Q.-T.; Li, G.; Luo, C.-X.; Yin, S.-H.; Lu, B.-A.; Xiao, C.; Xu, B.-B.; et al. Intermetallic PtBi nanoplates with high catalytic activity towards electrooxidation of formic acid and glycerol. ChemElectroChem 2020, 7, 239-245. [CrossRef]

30. Zhang, Y.; Qiao, M.; Huang, Y.; Zou, Y.; Liu, Z.; Tao, L.; Li, Y.; Dong, C.L.; Wang, S. In situ exfoliation and Pt deposition of antimonene for formic acid oxidation via a predominant dehydrogenation pathway. Research 2020, 2020, 5487237. [CrossRef]

31. Sawy, E.N.E.; Pickup, P.G. Carbon monoxide and formic acid oxidation at Rh@Pt nanoparticles. Electrochim. Acta 2019, 302, 234-240. [CrossRef]

32. El-Nagar, G.A.; Mohammad, A.M.; El-Deab, M.S.; El-Anadouli, B.E. Electrocatalysis of formic acid electro-oxidation at platinum nanoparticles modified surfaces with nickel and cobalt oxides nanostructures. In Progress in Clean Energy; Dincer, I., Colpan, C., Kizilkan, O., Ezan, M., Eds.; Springer International Publishing: Cham, Switzerland, 2015; Volume 1. [CrossRef]

33. El-Nagar, G.A.; Mohammad, A.M. Enhanced electrocatalytic activity and stability of platinum, gold, and nickel oxide nanoparticles based ternary catalyst for formic acid electro-oxidation. Int. J. Hydrogen Energy 2014, 39, 11955-11962. [CrossRef]

34. Mohammad, A.M.; El-Nagar, G.A.; Al-Akraa, I.M.; El-Deab, M.S.; El-Anadouli, B.E. Towards improving the catalytic activity and stability of platinum-based anodes in direct formic acid fuel cells. Int. J. Hydrogen Energy 2015, 40, 7808-7816. [CrossRef]

35. El-Refaei, S.M.; El-Nagar, G.A.; Mohammad, A.M.; El-Deab, M.S.; El-Anadouli, B.E. Electrocatalytic activity of NiOx nanostructured modified electrodes towards oxidation of small organic molecules. In Springer Proceedings in Energy, Proceedings of the 2nd International Congress on Energy Efficiency and Energy Related Materials (ENEFM2014), 16-19 October 2014; Oral, A., Bahsi Oral, Z., Ozer, M., Eds.; Springer: Cham, Switzerland, 2015. [CrossRef]

36. El-Nagar, G.A.; Mohammad, A.M.; El-Deab, M.S.; El-Anadouli, B.E. Propitious dendritic $\mathrm{Cu}_{2} \mathrm{O}-\mathrm{Pt}$ nanostructured anodes for direct formic acid, Fuel cells. ACS Appl. Mater. Interf. 2017, 9, 19766-19772. [CrossRef]

37. Ali Al-Qodami, B.; Farrag, H.H.; Sayed, S.Y.; Allam, N.K.; El-Anadouli, B.E.; Mohammad, A.M. Bifunctional tailoring of platinum surfaces with earth abundant iron oxide nanowires for boosted formic acid electro-oxidation. J. Nanotechnol. 2018, 2018, 4657040. [CrossRef]

38. Mohammad, A.M.; Al-Akraa, I.M.; El-Deab, M.S. Superior electrocatalysis of formic acid electrooxidation on a platinum, gold and manganese oxide nanoparticle-based ternary catalyst. Int. J. Hydrogen Energy 2018, 43, 139-149. [CrossRef]


lyst for enhanced formic acid electro-oxidation. J. Taiwan Inst. Chem. Eng. 2019, 96, 169-175. [CrossRef]

40. Santos, A.O.; Silva, J.C.M.; Antoniassi, E.R.M.; Ponzio, A.; Alves, O.C. The formate electrooxidation on $\mathrm{Pt} / \mathrm{C} \mathrm{and} \mathrm{PtSnO} 2 / \mathrm{C}$ nanoparticles in alkaline media: The effect of morphology and $\mathrm{SnO}_{2}$ on the platinum catalytic activity. Int. J. Hydrogen Energy 2020, 45, 33895-33905. [CrossRef]

41. Subbaraman, R.; Tripkovic, D.; Chang, K.-C.; Strmcnik, D.; Paulikas, A.P.; Hirunsit, P.; Chan, M.; Greeley, J.; Stamenkovic, V.; Markovic, N.M. Trends in activity for the water electrolyser reactions on $3 \mathrm{~d} \mathrm{M}(\mathrm{Ni} \mathrm{Co}, \mathrm{Fe}, \mathrm{Mn}$ ) hydr(oxy)oxide catalysts. Nat. Mater. 2012, 11, 550-557. [CrossRef]

42. El-Nagar, G.A.; Mohammad, A.M.; El-Deab, M.S.; El-Anadouli, B.E. Facilitated electrooxidation of formic acid at nickel oxide nanoparticles modified electrodes. J. Electrochem. Soc. 2012, 159, F249-F254. [CrossRef]

43. El-Nagar, G.A.; Mohammad, A.M.; El-Deab, M.S.; El-Anadouli, B.E. Electrocatalysis by design: Enhanced electrooxidation of formic acid at platinum nanoparticles-nickel oxide nanoparticles binary catalysts. Electrochim. Acta 2013, 94, 62-71. [CrossRef]

44. Fiameni, S.; Herraiz-Cardona, I.; Musiani, M.; Pérez-Herranz, V.; Vázquez-Gómez, L.; Verlato, E. The HER in alkaline media on Pt-modified three-dimensional Ni cathodes. Int. J. Hydrogen Energy 2012, 37, 10507-10516. [CrossRef]

45. Gu, Y.; Wang, Y.; Shi, J.; Yang, M.; Rui, Y.; An, W.; Men, Y. Well-dispersed Pt nanodots interfaced with Ni(OH $)_{2}$ on anodized nickel foam for efficient hydrogel evolution reaction. Int. J. Hydrogen Energy 2020, 45, 27067-27077. [CrossRef]

46. Yuan, S.; Cui, L.; He, X.; Zhang, W.; Asefa, T. Nickel foam-supported Fe, Ni-Polyporphyrin microparticles: Efficient bifunctional catalysts for overall water splitting in alkaline media. Int. J. Hydrogen Energy 2020, 45, 28860-28869. [CrossRef]

47. Wang, R.; Liu, H.; Zhang, K.; Zhang, G.; Lan, H.; Qu, J. Ni(II)/Ni(III) redox couple endows Ni foam-supported Ni 2 P with excellent capability for direct ammonia oxidation. Chem. Eng. J. 2021, 404, 126795. [CrossRef]

48. Yuan, G.; Wang, L.; Zhang, X.; Wang, Q. Self-supported Pt nanoflakes-doped amorphous $\mathrm{Ni}(\mathrm{OH})_{2}$ on Ni foam composite electrode for efficient and stable methanol oxidation. J. Colloid Interf. Sci. 2019, 536, 189-195. [CrossRef]

49. Sheng, S.; Song, Y.; Sha, L.; Ye, K.; Zhu, K.; Gao, Y.; Yan, J.; Wang, G.; Cao, D. Simultaneous hydrogen evolution and ethanol oxidation in alkaline medium via a self-supported bifunctional electrocatalyst of Ni-Fe phosphide/Ni foam. Appl. Surf. Sci. 2021, 561, 150080. [CrossRef]

50. Tamašauskaitė-Tamašiūnaitè, L.; Zabielaitè, A.; Balčiūnaitè, A.; Šebeka, B.; Stanionienè, I.; Buzas, V.; Mačiulis, L.; Tumonis, L.; Norkus, E. Deposition of Pt nanoparticles on Ni foam via galvanic displacement. J. Electrochem. Soc. 2017, 164, D53-D56. [CrossRef]

51. Song, C.; Wang, G.; Li, B.; Miao, C.; Ma, K.; Zhu, K.; Cheng, K.; Ye, K.; Yan, J.; Cao, D.; et al. A novel electrode of ternary CuNiPd nanoneedles decorated $\mathrm{Ni}$ foam and its catalytic activity toward $\mathrm{NaBH}_{4}$ electrooxidation. Electrochim. Acta 2019, 299, 395-404. [CrossRef]

52. Lei, Y.; Liu, Y.; Fan, B.; Mao, L.; Yu, D.; Huang, Y.; Guo, F. Facile fabrication of hierarchically porous Ni foam@Ag-Ni catalyst for efficient hydrazine oxidation in alkaline medium. J. Taiwan Inst. Chem. Eng. 2019, 105, 75-84. [CrossRef] 
53. Chen, N.; Wang, Y.; Du, X.; Zhang, X. Facile synthesis of Ni doped CoWO ${ }_{4}$ nanoarrays grown on nickel foam substrates for efficient urea oxidation. Int. J. Hydrogen Energy 2021, 46, 25114-25120. [CrossRef]

54. NIST X-ray Photoelectron Spectroscopy Database. NIST Standard Reference Database Number 20; National Institute of Standards and Technology: Gaithersburg, MD, USA, 2000; p. 20899. [CrossRef]

55. Igarashi, H.; Fujino, T.; Zhu, Y.; Uchida, H.; Watanabe, M. CO tolerance of Pt alloy electrocatalysts for polymer electrolyte fuel cells and the detoxification mechanism. Phys. Chem. Chem. Phys. 2001, 3, 306-314. [CrossRef]

56. Zhao, Y.; Yifeng, E.; Fan, L.; Qiu, Y.; Yang, S. A new route for the electrodeposition of platinum-nickel alloy nanoparticles on multi-walled carbon nanotubes. Electrochim. Acta 2007, 52, 5873-5878. [CrossRef]

57. Kim, K.S.; Winograd, N. X-ray photoelectron spectroscopic studies of nickel oxygen surfaces using oxygen and argon ionbombardment. Surf. Sci. 1974, 43, 625-643. [CrossRef]

58. Wittstok, G.; Strübing, A.; Szargan, R.; Werner, G. Glucose oxidation at bismuth-modified platinum electrodes. J. Electroanal. Chem. 1998, 444, 61-73. [CrossRef]

59. Blasini, D.R.; Rochefort, D.; Fachini, E.; Aldena, L.R.; DiSalvo, J.F.; Cabrera, C.R.; Abruna, H.D. Surface composition of ordered intermetallic compounds PtBi and PtPb. Surf. Sci. 2006, 600, 2670-2680. [CrossRef]

60. Eiler, K.; Krawiec, H.; Kozina, I.; Sort, J.; Pellicer, E. Electrochemical characterisation of multifunctional electrocatalytic mesoporous Ni-Pt thin films in alkaline and acidic media. Electrochim. Acta 2020, 359, 136952. [CrossRef]

61. Trasatti, S.; Petrii, O.A. Real surface area measurements in electrochemistry. Pure Appl. Chem. 1991, 63, 711-734. [CrossRef]

62. Daubinger, P.; Kieninger, J.; Unmussig, T.; Urban, G.A. Electrochemical characteristics of nanostructured platinum electrodes A cyclic voltammetry study. Phys. Chem. Chem. Phys. 2014, 16, 8392-8399. [CrossRef]

63. Dražić, D.M.; Tripković, A.V.; Popović, K.D.; Lović, D.J. Kinetic and mechanistic study of hydroxyl ion electrosorption at the Pt(111) surface in alkaline media. J. Electroanal. Chem. 1999, 466, 155-164. [CrossRef]

64. Schmidt, T.J.; Ross, P.N.; Marković, N.M. Temperature-dependent surface electrochemistry on Pt single crystals in alkaline electrolyte: Part 1: CO oxidation. J. Phys. Chem. B 2001, 105, 12082-12086. [CrossRef]

65. Tilak, B.V.; Conway, B.E.; Angerstain-Kozlowska, H. The real condition of oxidized Pt electrodes: Part III. Kinetic theory of formation and reduction of surface oxides. J. Electroanal. Chem. 1973, 48, 1-23. [CrossRef]

66. Marković, N.M.; Schmidt, T.J.; Grgur, B.N.; Gasteiger, H.A.; Ross, P.N.; Behm, R.J., Jr. Effect of temperature on surface processes at the $\mathrm{Pt}(111)$-liquid interface: Hydrogen adsorption, oxide formation, and CO oxidation. J. Phys. Chem. B. 1999, 103, 8568-8577. [CrossRef]

67. Tripković, A.V.; Popović, J.K.D.; Lović, D.J. The influence of the oxygen-containing species on the electrooxidation of the $\mathrm{C}_{1}-\mathrm{C}_{4}$ alcohols at some platinum single crystal surfaces in alkaline solution. Electrochim. Acta 2001, 46, 3163-3173. [CrossRef]

68. Marković, N.M.; Gasteiger, H.A.; Ross, P.N. Oxygen reduction on platinum low-index single-crystal surfaces in alkaline solution: Rotating ring disk $\mathrm{Pt}_{\mathrm{hkl}}$ studies. J. Phys. Chem. B 1996, 100, 6715-6721. [CrossRef]

69. Marković, N.M.; Sarraf, S.T.; Gasteiger, H.A.; Ross, P.N. Hydrogen electrochemistry on platinum low-index single-crystal surfaces in alkaline solution. J. Chem. Soc., Faraday Trans. 1996, 92, 3719-3725. [CrossRef]

70. Jiang, J.; Scott, J.; Wieckowski, A. Direct evidence of triple-path mechanism of formate electrooxidation on Pt black in alkaline media at varying temperature. Part I: The electrochemical studies. Electrochim. Acta 2013, 104, 124-133. [CrossRef]

71. Yan, L.; Yao, S.; Chang, J.; Liu, C.; Xing, W. Pd oxides/hydrous oxides as highly efficient catalyst for formic acid electrooxidation. J. Power Sources 2014, 250, 128-133. [CrossRef]

72. Okamoto, H.; Kon, W.; Mukouyama, Y. Five current peaks in voltammograms for oxidations of formic acid, formaldehyde, and methanol on platinum. J. Phys. Chem. B 2005, 109, 15659-15666. [CrossRef]

73. Šljukić, B.; Milikić, J.; Santos, D.M.F.; Sequeira, C.A.C.; Macciò, D.; Saccone, A. Electrocatalytic performance of Pt-Dy alloys for direct borohydride fuel cells. J. Power Sources 2014, 272, 335-343. [CrossRef]

74. Han, L.; Gonzilez-Cobos, J.; Sinchez-Molina, I.; Giancola, S.; Folkman, S.; Tang, P.; Heggen, M.; Dunin-Borkowski, R.; Arbiol, J.; Giménez, S.; et al. Cobalt hexacyanoferrate as a selective and high current density formate oxidation electrocatalyst. ACS Appl. Energy Mater. 2020, 3, 9198-9207. [CrossRef]

75. Galvan, V.; Glass, D.E.; Baxter, A.F.; Surya Prakash, G.K. Reduced graphene oxide supported palladium nanoparticles for enhanced electrocatalytic activity toward formate electrooxidation in an alkaline medium. ACS Appl. Energy Mater. 2019, 2, 7104-7111. [CrossRef]

76. Song, S.; Hwang, H.; Kim, J.W.; Lee, J. The effect of synthesis temperature on Pd-H catalyst structure for alkaline direct formate fuel cells. ECS Trans. 2018, 85, 149-158. [CrossRef]

77. Sankar, S.; Anilkumar, G.M.; Tamaki, T.; Yamaguchi, T. Binary Pd-Ni nanoalloy particles over carbon support with superior alkaline formate fuel electrooxidation performance. ChemCatChem 2019, 11, 4731-4737. [CrossRef] 